\title{
Consumption patterns of wild edibles by the Vasavas: a case study from Gujarat, India
}

Sonali Hasmukh Chauhan ${ }^{{ }^{*}}$ (D), Santosh Yadav ${ }^{2}$, Taro Takahashi ${ }^{3,4},{\text { Łukasz } \text { Łuczaj }^{5} \text {, Lancelot D'Cruz }}^{6}$ and Kensuke Okada ${ }^{1}$

\begin{abstract}
Background: Wild edibles continue to be a significant contributor to the global food basket in much of the developing world. A consensus has now been formed that information on wild edibles is an important part of ethnobotanical knowledge and hence elucidating region-specific patterns of habitat management and consumption assists policy making with regard to natural conservation, human nutrition, and human health. Using an original data set from Gujarat, India, the present research aims to document the collective knowledge of wild edibles possessed by the local Vasava tribe, as well as the habitat usage and consumption trends of these species.
\end{abstract}

Methods: Data were collected using three approaches: key informant interviews to record the local knowledge of wild edibles and methods of collection, village group discussions to quantify past and present consumption trends, and expert interviews to elucidate the reasons for changing consumption patterns.

Results: Through key informant interviews, 90 species of wild edibles from 46 botanical families were identified along with their Vasavi names, plant parts utilized, habitats, and cooking methods. Of these, 60 species were also used medicinally and 15 carried economic value. Different habitats were preferred for collection at different times of the year. Village group discussions unanimously concluded that the consumption of wild edibles has significantly reduced over time. Expert interviews identified the decreased availability of these species in their natural habitats as the most important reason for their reduced consumption.

Conclusion: The present study has demonstrated that the Vasavas' collective knowledge of wild edibles is vast and that these species contribute to their dietary diversity throughout the year. The finding of the present study, namely that anthropogenically managed habitats were often preferred over natural environments for the collection of wild edibles, suggests that conservation efforts should be extended beyond wild and human-uninhabited landscapes.

Keywords: Wild edibles, Ethnobotany, India, Gujarat, Wild food plants

\section{Background}

Wild plants are a crucial source of food, healthcare, and material subsistence in much of the developing world and carry a strong association with human livelihood [1-4]. Amongst wild plants, in particular, wild edible plants (WEP), once the most important food source for the human population, along with game food, continue to be significant contributors to the global food basket [5].

\footnotetext{
* Correspondence: sonalihchauhan@gmail.com

${ }^{1}$ Department of Global Agriculture Sciences, Graduate School of Agriculture and Life Sciences, The University of Tokyo, Tokyo 1138657, Japan Full list of author information is available at the end of the article
}

The word "wild" in this context refers to species that are not intentionally grown and managed by humans, including those minimally managed to prevent overgrowth or overharvest. This includes both native and alien plants, regardless of the preservation level of the habitats $[6,7]$.

Many earlier ethnobotanical works focused on lists of useful plants and had a strong tendency to focus on the scouting of new drug sources and new non-wood forest products (NWFP), both of which can be economically lucrative [8-12]. However, in recent years, there has been a growing interest in exploring the traditions of using wild plants beyond material and medicinal

(C) The Author(s). 2018 Open Access This article is distributed under the terms of the Creative Commons Attribution 4.0 International License (http://creativecommons.org/licenses/by/4.0/), which permits unrestricted use, distribution, and 
purposes and focus on wild edibles, as their roles become better understood in terms of local nutrition [2, 13-15], dietary diversity $[16,17]$, income generation $[4$, 18-21], healthcare [22, 23], reduction of micronutrient deficiency $[24,25]$, and food security through diversification [26-28]. There is now a consensus that information on wild edibles, including various modes of utilization and preparation, constitutes an important part of ethnobotanical knowledge and therefore that elucidating region-specific patterns of their habitat management and consumption assists policymaking in the areas of natural conservation, human nutrition, and healthcare $[29,30]$. This is particularly the case as a lack of extensive data is one of the major barriers that prevent optimal decision making tailored to local conditions.

There have been efforts to document WEP use traditions in India for a long time; however, due to the extreme diversity of the ethnic population of the Indian subcontinent, as well as its flora, the work is still in its infancy [31-42].

The research presented in this paper aims to document the collective knowledge of wild edibles possessed by the local Vasava tribe, as well as the habitat usage and consumption trends of these species. Previous ethnobotanical studies in Gujarat have exclusively focused on economically important species [43, 44], or ethnomedicinal uses $[43,45,46]$, so clear knowledge gap exists for the listing and habitat usage with respect to wild edibles.

\section{Methods}

\section{Study site}

Located in the western part of the country, the state of Gujarat is home to 29 Scheduled Tribes that together account for $14.8 \%$ of the state population. The Vasavas are one such tribe that have inhabited the Shoolpaneshwar forest belt, one of the dense forest belts within the state (Fig. 1). The medicine men "Bhagats" of Vasava tribe are known for their indigenous plant knowledge to treat illnesses of their community, part of which has recently been recorded from the pharmaceutical perspective [47]. The Vasavas are often described as subsistence farmers who possess traditional knowledge about plants due to close proximity to the forests. Nonetheless, rapid economic growth is inducing outmigration and transformation of land usage in the region, thereby threatening the survival of traditional knowledge as well as free access to forests for this tribe. Even though tribal areas in India often receive intervention programs for nutrition and livelihood enhancement, such programs have never been implemented in the study area, locally known as Dediapada Taluka.

The Shoolpaneshwar forest belt spans an area of $608 \mathrm{~km}^{2}$ over two Talukas, Dediapada and Sagbara, and is considered one of the rich biodiversity zones of the state (Fig. 1). The Narmada district, the administrative unit above them, has a forest cover of $41.5 \%$ across an area characterized by hilly terrain and a semi-arid climate. The district's average annual rainfall is $\sim 700 \mathrm{~mm}$, with 31 recorded rainy days (Fig. 2). There are two agricultural seasons, the rainy season (Kharif) from July to October and the post-rainy season (Rabi) from November to March. While all farmers cultivate during Kharif, only those with irrigation facilities plant a second crop during Rabi.

According to the 2011 district census data for Narmada, $85 \%$ of the total population are involved in agricultural production. At the same time, $65 \%$ of the total population earn their income as agricultural or industrial laborers, primarily because of small landholding, a phenomenon originating from land fragmentation through inheritance. The majority of the population lie below the poverty line and the literacy rate is low; in Dediapada Taluka, it is $65 \%$. Combined together, these factors force many Vasavas to out-migrate for alternative sources of livelihood, moving them away from their original ecological zone. As their "wisdom" concerning wild plants has typically been passed on from parents to children, limited access to forests by family members is thought to be threatening knowledge transfer.

According to the information collected during fieldwork, the staple source of carbohydrates for the Vasavas is rice while in hilly regions where paddy farming is difficult, it is maize. Other cereals such as sorghum, as well as indigenous millet such as bunti (Echinocloa crus-galli (L.) P.Beauv.), muu (Panicum pilosum Sw), kodri (Paspalum scrobiculatum L.), and bajro (Pennisetum typhoides (Burm.f.) Stapf \& C.E.Hubb.), are also consumed, along with cultivated vegetables (both heirloom and commercial varieties) grown in both agricultural fields and home gardens. Wild edibles form a major part of their complementary diet; for example, as much as $40 \%$ of the food consumed by the Bhil tribe, who live nearby, was sourced from non-agricultural fields [48], typically collected from nearby forests or their surroundings. For the Vasavas, a typical meal consists of a staple (rice, maize, sorghum, or millet) with vegetables and/or wild edibles, the latter of which are boiled, sautéed, or added to daal (a runny soup made with pulses). Meat, poultry, and fish can also be part of the Vasavas' diet depending on the family's economic reach and availability, while dairy products are severely limited due to the lack of storage facilities.

\section{Data collection}

In order to achieve the aforementioned aim of the research, local data were collected under three approaches: key informant interviews to record the Vasavas' 


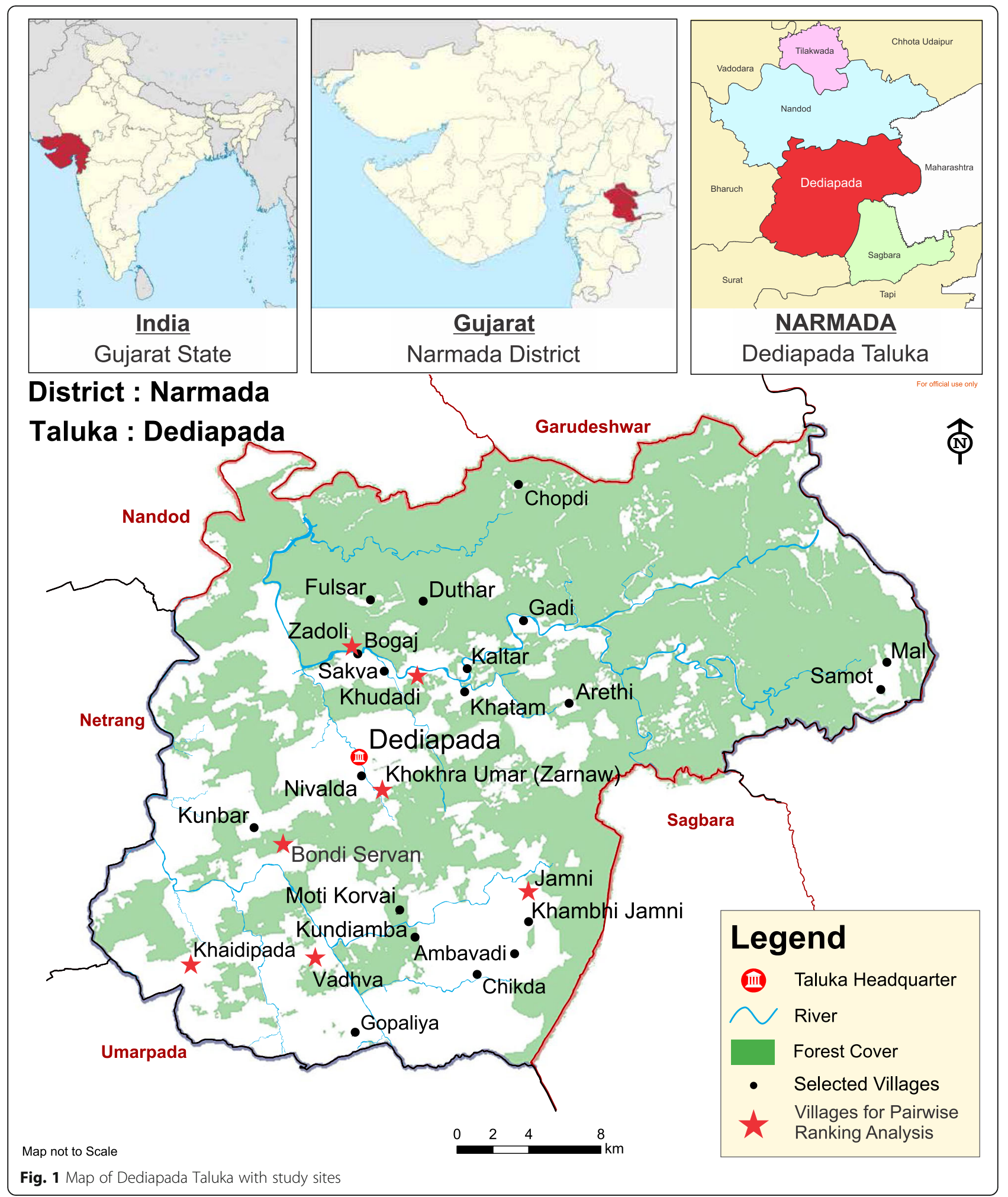

knowledge of wild edibles and methods of plant collection, village group interviews to quantify past and current consumption trends, and expert interviews to elucidate reasons for the decreased consumption of wild edibles.
Key informant interviews

Twenty-five key informants from 12 different villages (Fig. 1) were purposefully selected. Altogether, 14 men and 11 women were interviewed. Their ages ranged from 


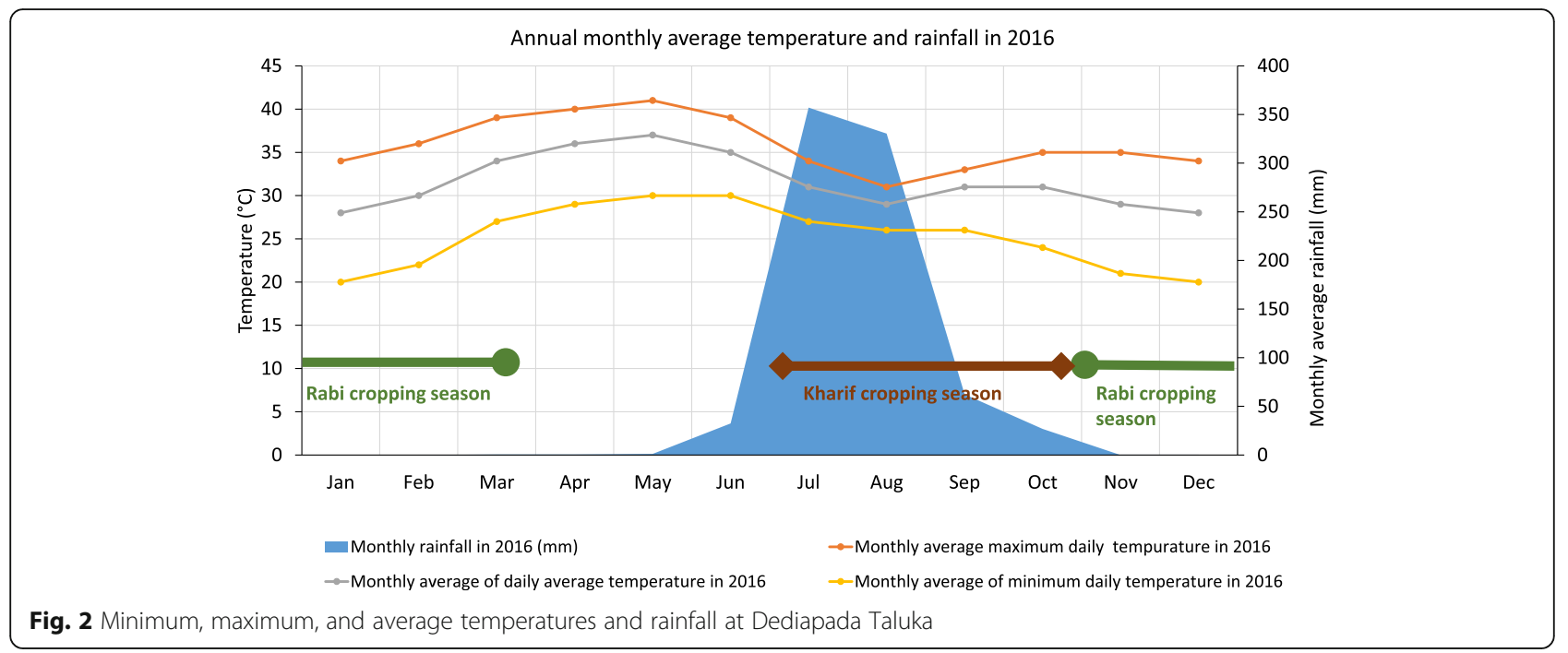

26 to 87 (mean 51.8, median 49). The studied settlements represent all the major ecological features of Dediapada Taluka. These key informants consisted of tribal healers and the local elders, who were considered the most knowledgeable about local plants within each village. Care was taken to include both genders from each village as, generally speaking, more men collect wild plants from forests, while more women are responsible for collecting and cooking plants from the village surroundings (e.g., home gardens) on a regular basis.

The interviews were conducted during the periods of August-September 2016 and December 2016-February 2017. The Gujarati language (the regional language) was used with occasional translation to the Vasavi language (the local tribal language). Each interview started with a field visit with the interviewee, which covered nearby forests, agricultural fields, and swamp habitats where edible plants were growing at the time of the survey. Information on the plant part used, typical recipes for cooking, potential for medicinal use, and the season, and primary locations of collection were noted. Each species was identified and photographically recorded in the field. Voucher specimens were also collected for species not already covered by previous floristic surveys carried out in the region. Following the field visit, each informant was interviewed again, inside their house, where the local names for the plants were confirmed and matched against photographs and dried specimens of the species, under the supervision of an experienced local taxonomist. The dried herbarium specimens of the species are identified by a taxonomist and stored at the herbarium of The Serenity Library \& Botanical Garden (for details, refer to "Availability of data and materials").At the conclusion of all interviews, a comprehensive list of wild edibles utilized by the Vasavas was compiled. This list was subsequently used to analyze habitat distribution and seasonal consumption patterns, as described below in the "Data analysis" section.

\section{Village group discussions}

Village heads, local school officials, and long-term residents from 12 villages (96 respondents) were invited to group discussions, held in August-September 2016, about the past and current trends surrounding the consumption of wild edibles. These open-ended interviews were carried out at either village schools or the homes of village heads/key informants. When the snowball technique was employed to maximize the amount of information collected, care was taken to include participants of various age groups from both genders.

\section{Expert interviews}

Structured questionnaire surveys were conducted with seven experts from different villages (Bondiservan, Vadhwa, Khudadi, Khokhraumar, Zadoli, Khairdipada, and Jamni villages), who were selected based on the recommendation of village heads during the group discussions. The questionnaire was based on the input obtained from the village group discussions and designed as a multi-purpose survey. The results presented in this paper primarily focus on the reasons for changing consumption patterns of wild edibles, obtained by means of pairwise comparisons [23, 49], encompassing six alternatives. The scores derived for each reason were aggregated across seven experts, producing an overall score that can take any value between 0 and 35 .

\section{Data analysis}

\section{Categorization of species}

Each species included in the plant list (prepared from key informant interviews) was categorized into one of five groups based on its habit (trees, shrubs, herbs, 
twiners, climbers), and one of the seven groups based on the habitat from which it was primarily collected (village, forest, swamp, village and forest, swamp and forest, village and swamp, all three locations). Here, a village habitat was defined as an environment that was fully or partially anthropologically managed (Fig. 3a-c). A forest habitat was defined as an area minimally managed by humans (although they are often close to villages), and a swamp habitat as a location where water bodies were present for most of the year, for example puddles, small riverines, and ponds. This grouping was based on the most common habitats from which each species was collected and therefore does not imply non-presence of the species in other locations.

The parts of the plants utilized were also categorized into six groups (leaves, flowers, seeds/fruits, underground parts, young shoots, multiple parts). The fourth group (underground parts) represents all storage organs including tubers, bulbs, corms, and rhizomes. The last group (multiple parts) covers species that are primarily collected for non-edible purposes but of which organs (same or different) are also used as human food.

Local names for plants in the compiled species list were transcribed into English with phonetic intuition, as the Vasavi language does not have a written script.
Typical months of collection and typical methods of cooking were also recorded in this list, so as to obtain insight into the Vasavas' culinary outlook and nutritional status.

A complete plant list was compiled with their Vasavi names, scientific names, plant parts utilized, primary habitats, and cooking methods. This aggregated information was further used for analyzing the consumption and collection patterns as described in the "Results" section.

\section{Consumption and collection patterns}

Following the compilation of the species list, the number of species collected from each habitat category was quantified. This value was used as an indicator for the seasonal availability of the plants and for the locations of actual collection events [50]. Since the primary focus of the present study was on usage patterns of habitats for sourcing these species, the number of species was judged to offer better insights than the level of biomass available, a common indicator for sustainable harvesting. The number of species collected for each plant part was also collated to evaluate the potential of wild edibles to provide diverse pathways of nutrient acquisition. The information collected from the village group discussions and

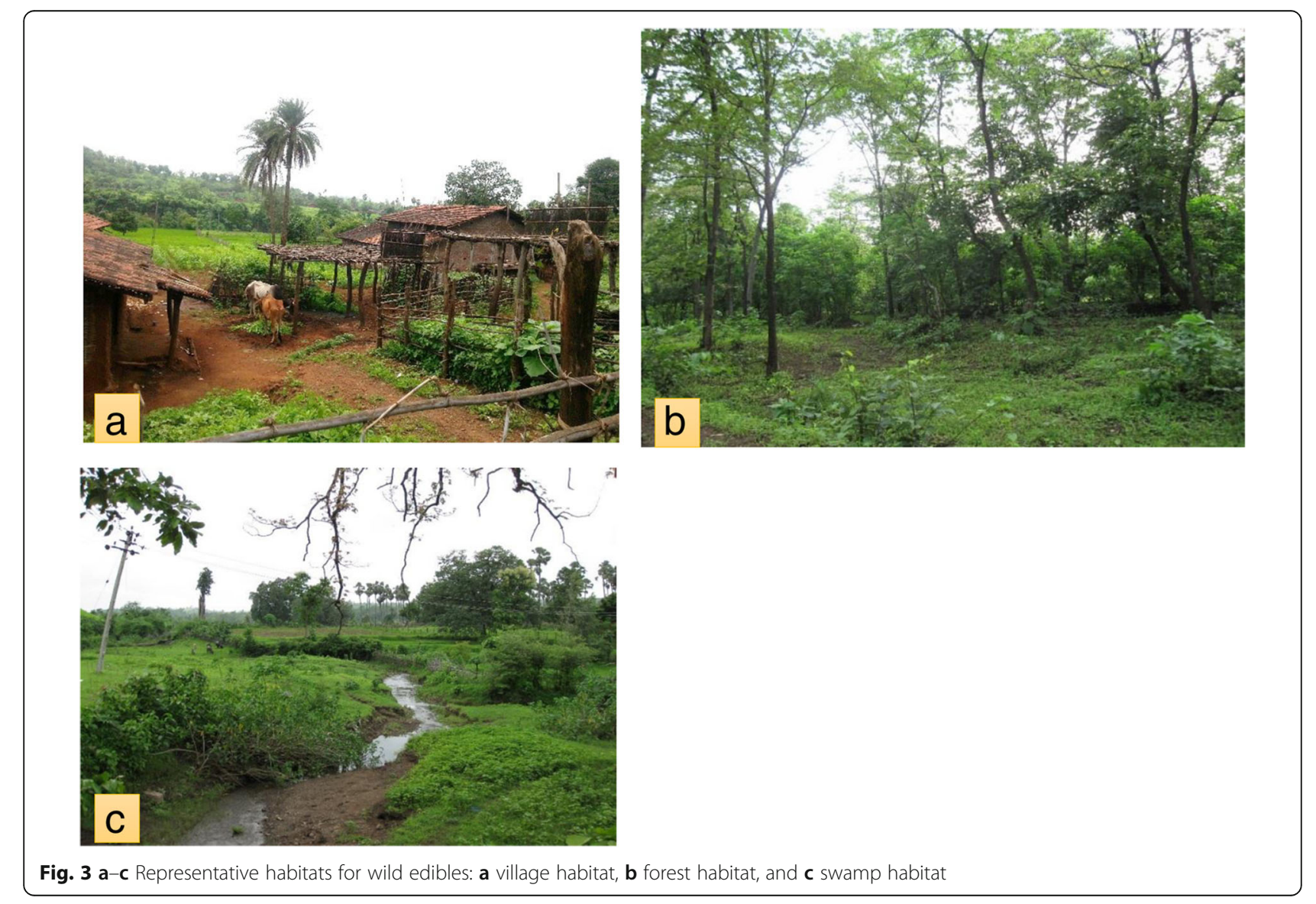


Table 1 List of wild edible species used by the Vasavas

\begin{tabular}{|c|c|c|c|c|c|c|c|c|}
\hline Sr. No. & $\begin{array}{l}\text { Botanical names and } \\
\text { collection number }\end{array}$ & Season & Family/sub family & Vasavi name & $\begin{array}{l}\text { Plant } \\
\text { type }\end{array}$ & $\begin{array}{l}\text { Plant } \\
\text { part } \\
\text { used }\end{array}$ & $\begin{array}{l}\text { Habitat/ } \\
\text { location }\end{array}$ & Recipe and use \\
\hline 1 & $\begin{array}{l}\text { Achyranthes aspera L. } \\
\text { TSLBG: } 2402\end{array}$ & June-Dec & Amaranthaceae & Arpchinjudo & 2 & 1 & 4 & $\begin{array}{l}\text { The leaves are consumed as leafy } \\
\text { vegetables either boiled or stir-fried } \\
\text { with spices }\end{array}$ \\
\hline 2 & $\begin{array}{l}\text { Aegle marmelos (L.) } \\
\text { Corr. TSLBG: } 2413\end{array}$ & April-June & Rutaceae & Bila (Bili) & 1 & 3 & 1 & $\begin{array}{l}\text { Unripe fruit is pickled, and ripe fruit } \\
\text { is consumed directly or in the form } \\
\text { of a juice }\end{array}$ \\
\hline 3 & $\begin{array}{l}\text { Alangium salvifolium } \\
\text { (L. f.) Wang. TSLBG: } \\
2483\end{array}$ & Oct-Jan & Alangiaceae & Aakna & 1 & 3 & 1 & $\begin{array}{l}\text { The fruit is edible, and the twig is } \\
\text { used as a dental floss }\end{array}$ \\
\hline 4 & $\begin{array}{l}\text { Alternanthera sessilis L. } \\
\text { TSLBG: } 2454\end{array}$ & June-Oct & Amaranthaceae & Ganthiyu & 2 & 1 & 4 & $\begin{array}{l}\text { The leaves are boiled and consumed } \\
\text { as leafy vegetables with spices }\end{array}$ \\
\hline 5 & $\begin{array}{l}\text { Amaranthus hybridus } \\
\text { L. TSLBG: } 2548\end{array}$ & June-Nov & Amaranthaceae & Laal matnu & 3 & 1 & 7 & $\begin{array}{l}\text { Leaves are boiled and drained, and } \\
\text { chili spice and salt are added for flavor }\end{array}$ \\
\hline 6 & $\begin{array}{l}\text { Amaranthus spinosus } \\
\text { L. TSLBG: } 2464\end{array}$ & June-Nov & Amaranthaceae & Kantalomatnu & 3 & 1 & 7 & $\begin{array}{l}\text { Leaves are boiled, and spices are } \\
\text { added. Sometimes addition of } \\
\text { khatibhindi (Hibiscus sabdarifa) }\end{array}$ \\
\hline 7 & $\begin{array}{l}\text { Amaranthus viridis } L \text {. } \\
\text { TSLBG: } 2558\end{array}$ & June-Nov & Amaranthaceae & Matnu & 3 & 1 & 7 & $\begin{array}{l}\text { Leaves are boiled, and spices are } \\
\text { added }\end{array}$ \\
\hline 8 & $\begin{array}{l}\text { Annona squamosa L. } \\
\text { TSLBG: } 2409\end{array}$ & Sept-Nov & Annonaceae & Aanusari & 1 & 6 & 4 & $\begin{array}{l}\text { The fruits are edible when ripe. The } \\
\text { roots, leaves, and bark are used } \\
\text { medicinally }\end{array}$ \\
\hline 9 & $\begin{array}{l}\text { Argyreia nervosa } \\
\text { (Burm. f) Boj TSLBG: } \\
2540\end{array}$ & June-Oct & Convolvulaceae & Panjo & 5 & 6 & 4 & Tender leaves are boiled or sautéed \\
\hline 10 & $\begin{array}{l}\text { Arisaema tortuosum } \\
\text { (Wall.) Schott. TSLBG: } \\
2502\end{array}$ & June-July & Apaceae & Vayu & 3 & 5 & 4 & $\begin{array}{l}\text { The young tender petiole of the } \\
\text { plant is soaked overnight in salt } \\
\text { water to reduce the mucilage and } \\
\text { then pickled or cooked in sour } \\
\text { yoghurt or buttermilk with spices } \\
\text { as a vegetable }\end{array}$ \\
\hline 11 & $\begin{array}{l}\text { Asparagus racemosus } \\
\text { Willd. TSLBG: } 2414\end{array}$ & All year & Liliaceae & Shatavari & 2 & 4 & 4 & $\begin{array}{l}\text { Root is boiled removing the central } \\
\text { vein and stir-fried with oil and spices; } \\
\text { soup of boiled roots is also prepared }\end{array}$ \\
\hline 12 & $\begin{array}{l}\text { Azadirachta indica A. } \\
\text { Juss. TSLBG: } 2429\end{array}$ & March-June & Meliaceae & Limdo & 1 & 6 & 1 & The ripe fruit pulp is edible \\
\hline 13 & $\begin{array}{l}\text { Bacopa monnieri (L.) } \\
\text { Wettest. TSLBG: } 2438\end{array}$ & Sept-Jan & Scrophulariaceae & Nirbrahmi/Bam & 3 & 1 & 3 & $\begin{array}{l}\text { Washed thoroughly and prepared } \\
\text { with onions and spices or boiled }\end{array}$ \\
\hline 14 & $\begin{array}{l}\text { Bambusa } \\
\text { arundinacea(Retz.) } \\
\text { Willd. TSLBG: } 2415\end{array}$ & $\begin{array}{l}\text { Once after } \\
25 \text { years }\end{array}$ & Poaceae & Vans & 1 & 5 & 2 & $\begin{array}{l}\text { The young shoot is boiled and } \\
\text { stir-fried to a vegetable, or young } \\
\text { shoot is boiled and made in to pickle } \\
\text { with spices }\end{array}$ \\
\hline 15 & $\begin{array}{l}\text { Bauhinia racemosa } \\
\text { Lam. TSLBG: } 2411\end{array}$ & Feb-May & Caesalpiniae & Aachitro, Hinglo & 1 & 2 & 1 & $\begin{array}{l}\text { The young leaves and flowers are } \\
\text { used as stir-fried vegetable }\end{array}$ \\
\hline 16 & $\begin{array}{l}\text { Bauhinia vahlii } \\
\text { Graham TSLBG: } 2417\end{array}$ & Feb-May & Caesalpiniae & Aavalvel & 4 & 3 & 2 & $\begin{array}{l}\text { The young leaves and flowers are } \\
\text { used as stir-fried vegetable }\end{array}$ \\
\hline 17 & $\begin{array}{l}\text { Benkara pundulacakai } \\
\text { (Gmelin.) Almeida. } \\
\text { TSLBG: } 2422\end{array}$ & June-July & Rubiaceae & Gungur (flower) & 2 & 2 & 2 & $\begin{array}{l}\text { The flowers are washed and stir-fried } \\
\text { in oil and spices }\end{array}$ \\
\hline 18 & $\begin{array}{l}\text { Boerhavia diffusa L. } \\
\text { TSLBG: } 2501\end{array}$ & All year & Nyctaginaceae & $\begin{array}{l}\text { Dhagarphodiyu/ } \\
\text { Patharphodiyu }\end{array}$ & 3 & 6 & 1 & $\begin{array}{l}\text { Stir-fried vegetable in yoghurt with } \\
\text { spices or boiled }\end{array}$ \\
\hline 19 & $\begin{array}{l}\text { Bombax ceiba L. } \\
\text { TSLBG: } 2564\end{array}$ & Feb-March & Bombacaceae & Hambo, Samro & 1 & 2 & 2 & $\begin{array}{l}\text { Flowers are used to make stir-fry curry } \\
\text { in oil, or they are boiled with spices }\end{array}$ \\
\hline 20 & $\begin{array}{l}\text { Borassus flabellifer } \\
\text { Linn. TSLBG: } 2484\end{array}$ & Feb-May & Palmaceae & Tad & 1 & 6 & 4 & $\begin{array}{l}\text { The sap from the inflorescence is } \\
\text { collected in an earthen pot, and } \\
\text { the juice is either fresh or consumed } \\
\text { in the evening after some } \\
\text { fermentation. Fruit is also edible }\end{array}$ \\
\hline
\end{tabular}


Table 1 List of wild edible species used by the Vasavas (Continued)

\begin{tabular}{|c|c|c|c|c|c|c|c|c|}
\hline Sr. No. & $\begin{array}{l}\text { Botanical names and } \\
\text { collection number }\end{array}$ & Season & Family/sub family & Vasavi name & $\begin{array}{l}\text { Plant } \\
\text { type }\end{array}$ & $\begin{array}{l}\text { Plant } \\
\text { part } \\
\text { used }\end{array}$ & $\begin{array}{l}\text { Habitat/ } \\
\text { location }\end{array}$ & Recipe and use \\
\hline 21 & $\begin{array}{l}\text { Borreria articularis (L.f.) } \\
\text { F.N.Williams TSLBG: } \\
2420\end{array}$ & $\begin{array}{l}\text { All year } \\
\text { round }\end{array}$ & Rubiaceae & Ganthi & 3 & 1 & 1 & $\begin{array}{l}\text { The leaves are used and are boiled } \\
\text { with some spices or stir-fried in oil }\end{array}$ \\
\hline 22 & $\begin{array}{l}\text { Bridelia squamosa } \\
\text { (Lamk.) Gehrmann. } \\
\text { TSLBG: } 2435\end{array}$ & Jan-Feb & Euphorbiaceae & Akano (1) & 1 & 3 & 2 & $\begin{array}{l}\text { The fruits are edible when ripe. The } \\
\text { roots, leaves, and bark are used } \\
\text { medicinally }\end{array}$ \\
\hline 23 & $\begin{array}{l}\text { Buchanania } \\
\text { cochinchinensis (Lour.) } \\
\text { Almeida TSLBG: } 2509\end{array}$ & Feb-May & Anacardiaceae & Charoli & 1 & 3 & 2 & $\begin{array}{l}\text { The fruit is edible and eaten when } \\
\text { ripe }\end{array}$ \\
\hline 24 & $\begin{array}{l}\text { Cassia tora L. TSLBG: } \\
2425\end{array}$ & June-Aug & Fabaceae & Chinjudo & 2 & 6 & 4 & $\begin{array}{l}\text { The small tender leaves are edible } \\
\text { as a leafy vegetable or as a } \\
\text { stir-fried with oil and spices }\end{array}$ \\
\hline 25 & $\begin{array}{l}\text { Celosia argentea L. } \\
\text { TSLBG: } 2444\end{array}$ & June-Oct & Amaranthaceae & Lemdi & 2 & 1 & 1 & $\begin{array}{l}\text { The leaves are eaten as a leafy } \\
\text { vegetable either boiled or stir-fried } \\
\text { in oil with spices }\end{array}$ \\
\hline 26 & $\begin{array}{l}\text { Ceropegia bulbosa } \\
\text { Roxb. TSLBG: } 2427\end{array}$ & July-Aug & Asclepiadaceae & Sap okoni & 3 & 4 & 1 & $\begin{array}{l}\text { The tubers are edible. The tubers } \\
\text { are boiled and added with crushed } \\
\text { chili flakes }\end{array}$ \\
\hline 27 & $\begin{array}{l}\text { Ceropegia fantastica } \\
\text { Sed. TSLBG: } 2555\end{array}$ & July-Aug & Asclepiadaceae & Okoni & 3 & 4 & 1 & $\begin{array}{l}\text { The tubers are edible. The tubers } \\
\text { are boiled and added with crushed } \\
\text { chili flakes }\end{array}$ \\
\hline 28 & $\begin{array}{l}\text { Chenopodium album } \\
\text { L. TSLBG: } 2546\end{array}$ & June-Nov & Chenopodiaceae & ChilBhaji & 3 & 1 & 1 & $\begin{array}{l}\text { Leaves are cooked in buttermilk as } \\
\text { a vegetable }\end{array}$ \\
\hline 29 & $\begin{array}{l}\text { Chlorophytum } \\
\text { borivalianum Sant. \& } \\
\text { Fernand TSLBG: } 2498\end{array}$ & June-Aug & Liliaceae & Kuvlu & 3 & 1 & 2 & $\begin{array}{l}\text { The leaves and bulb are stir-fried } \\
\text { and eaten. The leaves are added in } \\
\text { daal sometimes }\end{array}$ \\
\hline 30 & $\begin{array}{l}\text { Chlorophytum } \\
\text { tuberosum (Roxb.) } \\
\text { Baker TSLBG: } 2447\end{array}$ & June-Aug & Liliaceae & Dholimusli/Kuvli & 3 & 6 & 2 & $\begin{array}{l}\text { The leaves are used in daal as a } \\
\text { vegetable }\end{array}$ \\
\hline 31 & $\begin{array}{l}\text { Clematis hedysarifolia } \\
\text { DC. TSLBG: } 2506\end{array}$ & June-Aug & Ranunculaceae & Kukadvel & 5 & 5 & 4 & $\begin{array}{l}\text { The tender stem is used as a } \\
\text { vegetable }\end{array}$ \\
\hline 32 & $\begin{array}{l}\text { Cocculus hirsutus (L.) } \\
\text { Diels. TSLBG: } 2519\end{array}$ & $\begin{array}{l}\text { All year } \\
\text { round }\end{array}$ & Menispermiaceae & Vasano/Vasanvel & 5 & 1 & 4 & $\begin{array}{l}\text { Can be eaten raw or boiled and } \\
\text { stir-fried in spices after draining } \\
\text { water }\end{array}$ \\
\hline 33 & $\begin{array}{l}\text { Commelina } \\
\text { benghalensis L. TSLBG: } \\
2475\end{array}$ & June-Aug & Commelinaceae & Keniyu & 3 & 1 & 7 & $\begin{array}{l}\text { The tender leaves are stir-fried and } \\
\text { eaten }\end{array}$ \\
\hline 34 & $\begin{array}{l}\text { Commelina diffusa L. f. } \\
\text { TSLBG: } 2513\end{array}$ & June-Aug & Commelinaceae & Punyopujyu & 3 & 1 & 6 & $\begin{array}{l}\text { The tender leaves are stir-fried in oil } \\
\text { and eaten with crushed chilies and } \\
\text { salt }\end{array}$ \\
\hline 35 & $\begin{array}{l}\text { Commelina obliqua } \\
\text { Vahl. TSLBG: } 2450\end{array}$ & June-Aug & Commelinaceae & Narelu & 3 & 1 & 6 & $\begin{array}{l}\text { Tender leaves are edible and eaten } \\
\text { stir-fried with oil and spices }\end{array}$ \\
\hline 36 & $\begin{array}{l}\text { Cordia dichotoma } \\
\text { Forst. f. TSLBG: } 2471\end{array}$ & $\begin{array}{l}\text { Dec-Feb } \\
\text { (flower) } \\
\text { March-June } \\
\text { fruit }\end{array}$ & Ebenaceae & $\begin{array}{l}\text { Gunda } \\
\text { (green and chikna) }\end{array}$ & & 6 & 4 & $\begin{array}{l}\text { Inflorescence is cooked stir-fried with } \\
\text { yoghurt and spices. The unripe fruit } \\
\text { is used for making pickle }\end{array}$ \\
\hline 37 & $\begin{array}{l}\text { Cordia gharaf (Forsk.) } \\
\text { E. \& A. TSLBG: } 2524\end{array}$ & Dec-May & Ehretiaceae & Gundi & 1 & 3 & 1 & $\begin{array}{l}\text { The ripe fruit is consumed, and } \\
\text { unripe fruit is pickled }\end{array}$ \\
\hline 38 & $\begin{array}{l}\text { Dalbergia volubilis } \\
\text { Roxb. TSLBG: } 2561\end{array}$ & June-Nov & Fabaceae & Kinhariyu/Pingush & 5 & 1 & 1 & $\begin{array}{l}\text { The tender leaves are cooked as a } \\
\text { leafy vegetable as a stir-fried in oil } \\
\text { and spices }\end{array}$ \\
\hline 39 & $\begin{array}{l}\text { Dendrocalamus } \\
\text { strictus (Roxb.) Nees } \\
\text { TSLBG: } 2445\end{array}$ & July-Aug & Poaceae & Vans nibhaaji & & 5 & 2 & $\begin{array}{l}\text { Tender just emerged shoot apex is } \\
\text { boiled and cut and made in pickle } \\
\text { and made into vegetable }\end{array}$ \\
\hline 40 & $\begin{array}{l}\text { Dioscorea belophylla } \\
\text { Voigt. TSLBG: } 2469\end{array}$ & Aug-Sept & Dioscoreaceae & Huvi & 4 & 4 & 4 & $\begin{array}{l}\text { The bulbil is similar to Taro and is } \\
\text { boiled and cooked similarly in oil } \\
\text { and spices }\end{array}$ \\
\hline
\end{tabular}


Table 1 List of wild edible species used by the Vasavas (Continued)

\begin{tabular}{|c|c|c|c|c|c|c|c|c|}
\hline Sr. No. & $\begin{array}{l}\text { Botanical names and } \\
\text { collection number }\end{array}$ & Season & Family/sub family & Vasavi name & $\begin{array}{l}\text { Plant } \\
\text { type }\end{array}$ & $\begin{array}{l}\text { Plant } \\
\text { part } \\
\text { used }\end{array}$ & $\begin{array}{l}\text { Habitat/ } \\
\text { location }\end{array}$ & Recipe and use \\
\hline 41 & $\begin{array}{l}\text { Dioscorea bulbifera L. } \\
\text { TSLBG: } 2482\end{array}$ & June-July & Dioscoreaceae & Kadvokand & 4 & 4 & 4 & $\begin{array}{l}\text { The bulbil is boiled or soaked } \\
\text { overnight in salt to remove } \\
\text { bitterness and then cooked like } \\
\text { potato with oil and spices and } \\
\text { sometimes in buttermilk }\end{array}$ \\
\hline 42 & $\begin{array}{l}\text { Dioscorea hispida } \\
\text { Dennstd. TSLBG: } 2521\end{array}$ & Aug-Sept & Dioscoreaceae & Manovaj & 4 & 4 & 4 & $\begin{array}{l}\text { The bulbil is similar to Taro and is } \\
\text { boiled and cooked similarly in oil } \\
\text { and spices and sometimes in } \\
\text { buttermilk }\end{array}$ \\
\hline 43 & $\begin{array}{l}\text { Dioscorea pentaphylla } \\
\text { L. TSLBG: } 2463\end{array}$ & Aug-Sept & Dioscoreaceae & Huvdo & 4 & 4 & 4 & $\begin{array}{l}\text { The bulbil is similar to Taro and is } \\
\text { boiled and cooked similarly in oil } \\
\text { and spices and sometimes in } \\
\text { buttermilk }\end{array}$ \\
\hline 44 & $\begin{array}{l}\text { Dioscorea wallichii Hk. } \\
\text { TSLBG: } 2530\end{array}$ & Aug-Sept & Dioscoreaceae & Chaydu & 4 & 4 & 4 & $\begin{array}{l}\text { The bulbils is similar to Taro and is } \\
\text { boiled and cooked similarly in oil } \\
\text { and spices and sometimes in } \\
\text { buttermilk }\end{array}$ \\
\hline 45 & $\begin{array}{l}\text { Diospyros melanoxylon } \\
\text { Roxb. TSLBG: } 2448\end{array}$ & May-June & Ebenaceae & Timru & 1 & 6 & 2 & $\begin{array}{l}\text { Fruit is consumed for its sweet } \\
\text { taste; unripe fruits are picked from } \\
\text { forest and ripened in sandy soil. } \\
\text { Leaves are used for making local } \\
\text { handmade cigarette (bidi) }\end{array}$ \\
\hline 46 & $\begin{array}{l}\text { Dregea volubilis (L.f.) } \\
\text { Benth. ex Hook.f. } \\
\text { TSLBG: } 2431\end{array}$ & Sept-Feb. & Asclepiadaceae & Kadvishir & 5 & 3 & 1 & $\begin{array}{l}\text { The young leaves and stems are } \\
\text { boiled and drained and eaten with } \\
\text { crushed chili and salt }\end{array}$ \\
\hline 47 & $\begin{array}{l}\text { Enicostema littorale Bl. } \\
\text { TSLBG: } 2488\end{array}$ & June-Aug & Gentianaceae & $\begin{array}{l}\text { Mamejavo/ } \\
\text { KadviNai }\end{array}$ & 3 & 1 & 1 & Tender leaves stir-fried as vegetable \\
\hline 48 & $\begin{array}{l}\text { Eulophia herbacea } \\
\text { Lindl. TSLBG: } 2497\end{array}$ & July-Sept & Orchidaceae & Waghmodhu & 3 & 2 & 1 & Inflorescence is cooked \\
\hline 49 & $\begin{array}{l}\text { Ficus hispida L.f. } \\
\text { TSLBG: } 2507\end{array}$ & May-July & Moraceae & Umbo/Koth Umbo & 1 & 3 & 1 & $\begin{array}{l}\text { Fruit edible and much enjoyed by } \\
\text { kids, leaves medicinal }\end{array}$ \\
\hline 50 & $\begin{array}{l}\text { Flueggea microcarpa } \\
\text { BI. TSLBG: } 2489\end{array}$ & July-Nov & Euphorbiaceae & Safed chini & 2 & 3 & 1 & The white, ripe fruits are edible \\
\hline 51 & $\begin{array}{l}\text { Garuga pinnata Roxb. } \\
\text { TSLBG: } 2494\end{array}$ & Jan-May & Burseraceae & Kakaro & 1 & 3 & 1 & Pickle is made up of fruits \\
\hline 52 & $\begin{array}{l}\text { Grewia hirsuta Vahl. } \\
\text { TSLBG: } 2495\end{array}$ & $\begin{array}{l}\text { Aug- } \\
\text { October }\end{array}$ & Tiliaceae & Tamna & 1 & 3 & 2 & $\begin{array}{l}\text { Ripe fruit is edible raw and has } \\
\text { medicinal properties for stomach } \\
\text { disorders }\end{array}$ \\
\hline 53 & $\begin{array}{l}\text { Grewia tiliaefolia Vahl. } \\
\text { TSLBG: } 2529\end{array}$ & $\begin{array}{l}\text { Aug- } \\
\text { October }\end{array}$ & Tiliaceae & Dhaman & 1 & 6 & 2 & $\begin{array}{l}\text { Ripe fruit is edible raw. Stem is } \\
\text { used for toothache as dental floss }\end{array}$ \\
\hline 54 & $\begin{array}{l}\text { Heracleum grandis } \\
\text { (Dalz. \& Gibs.) Mukh. } \\
\text { TSLBG: } 2532\end{array}$ & All year & Umbelliferae & Bokhudo & 2 & 6 & 3 & $\begin{array}{l}\text { Stir-fried vegetable of the leaves } \\
\text { either boiled or stir-fried with oil } \\
\text { and spices }\end{array}$ \\
\hline 55 & $\begin{array}{l}\text { Holarhena } \\
\text { antidysenterica (Heyne } \\
\text { ex Roth) Wall. ex DC. } \\
\text { TSLBG: } 2451\end{array}$ & June-Aug & Apocynaceae & Kunvad & 2 & 1 & 4 & $\begin{array}{l}\text { The tender leaves are made into a } \\
\text { leafy vegetable }\end{array}$ \\
\hline 56 & $\begin{array}{l}\text { Holoptelea integrifolia } \\
\text { (Roxb.) Planch TSLBG: } \\
2441\end{array}$ & Jan-May & Ulmaceae & Kunjo, Punjo & 1 & 3 & 1 & $\begin{array}{l}\text { The leaves are boiled and drained } \\
\text { and eaten with added spices }\end{array}$ \\
\hline 57 & $\begin{array}{l}\text { Holostemma } \\
\text { annularium (Roxb.) K } \\
\text { Schum. TSLBG: } 2534\end{array}$ & June-Aug & Asclepiadaceae & Nanshiri/meethishir & 4 & 6 & 2 & $\begin{array}{l}\text { Tender leaves are used as } \\
\text { vegetables, and flowers are bit sweet } \\
\text { and edible as well. Medicinally, the } \\
\text { leaves and roots are used for } \\
\text { menstrual disorders and period pain }\end{array}$ \\
\hline 58 & $\begin{array}{l}\text { Ipomoea marginata } \\
\text { (Desr.) Verdc. TSLBG: } \\
2432\end{array}$ & June-Oct & Convolvulaceae & Panjvu & 5 & 1 & 7 & $\begin{array}{l}\text { The leaves are used as leafy } \\
\text { vegetable and is edible either } \\
\text { stir-fried or boiled with spices }\end{array}$ \\
\hline
\end{tabular}


Table 1 List of wild edible species used by the Vasavas (Continued)

\begin{tabular}{|c|c|c|c|c|c|c|c|c|}
\hline Sr. No. & $\begin{array}{l}\text { Botanical names and } \\
\text { collection number }\end{array}$ & Season & Family/sub family & Vasavi name & $\begin{array}{l}\text { Plant } \\
\text { type }\end{array}$ & $\begin{array}{l}\text { Plant } \\
\text { part } \\
\text { used }\end{array}$ & $\begin{array}{l}\text { Habitat/ } \\
\text { location }\end{array}$ & Recipe and use \\
\hline 59 & $\begin{array}{l}\text { Ipomoea aquatica } \\
\text { Forsk. TSLBG: } 2436\end{array}$ & All year & Convolvulaceae & $\mathrm{Nal}$ & 3 & 1 & 3 & $\begin{array}{l}\text { Stir-fried vegetable or boiled leaves } \\
\text { with added spices }\end{array}$ \\
\hline 60 & $\begin{array}{l}\text { Ipomoea carneassp. } \\
\text { Fistulosa (Mortex ex } \\
\text { Choisy) Austin TSLBG: } \\
2433\end{array}$ & July-Nov & Convolvulaceae & Nihuto & 2 & 1 & 1 & $\begin{array}{l}\text { The tender leaves after rain are } \\
\text { plucked and stir-fried into a } \\
\text { vegetable with oil and spices }\end{array}$ \\
\hline 61 & $\begin{array}{l}\text { Kirganelia reticulata } \\
\text { (Poir.) Bail. TSLBG: } \\
2442\end{array}$ & July-Aug & Euphorbiaceae & Kinhariyu/Kalichini & 2 & 1 & 1 & $\begin{array}{l}\text { Tender shoots and leaves are } \\
\text { stir-fried to make leafy vegetable } \\
\text { with oil and spices }\end{array}$ \\
\hline 62 & $\begin{array}{l}\text { Leea asiatica (L.) } \\
\text { Ridsdale TSLBG: } 2437\end{array}$ & Aug-Nov & Leeaceae & Nanidhini & 2 & 2 & 2 & $\begin{array}{l}\text { The inflorescence is cut and cooked } \\
\text { as a vegetable with oil and spices }\end{array}$ \\
\hline 63 & $\begin{array}{l}\text { Leea edgeworthii Sant. } \\
\text { TSLBG: } 2544\end{array}$ & July-Sept & Leeaceae & Nanudhinu & 2 & 5 & 2 & $\begin{array}{l}\text { The inflorescence is cut and cooked } \\
\text { as a vegetable with oil and spices }\end{array}$ \\
\hline 64 & $\begin{array}{l}\text { Leea macrophylla } \\
\text { Roxb. ex Hornem } \\
\text { TSLBG: } 2485\end{array}$ & July-Aug & Leeaceae & Motu Dhinu & 3 & 2 & 1 & $\begin{array}{l}\text { Cultural importance of leaves for } \\
\text { usage in ritual of offering first grain } \\
\text { of harvest and praying. Fruits } \\
\text { edible. Inflorescence is cooked as } \\
\text { vegetable stir-fried in oil with spices }\end{array}$ \\
\hline 65 & $\begin{array}{l}\text { Limonia acidissima L. } \\
\text { TSLBG: } 2520\end{array}$ & Nov-March & Rutaceae & Kotha & 1 & 3 & 1 & $\begin{array}{l}\text { The fruit pulp is edible after adding } \\
\text { some spices. It is usually made into a } \\
\text { chutney (thick sauce) with salt and } \\
\text { chili occasionally also adding sugar }\end{array}$ \\
\hline 66 & $\begin{array}{l}\text { Madhuca indica Gmel. } \\
\text { TSLBG: } 2473\end{array}$ & March-July & Sapotaceae & Mahuda & 1 & 6 & 2 & $\begin{array}{l}\text { Flower is fleshy and is sun-dried and } \\
\text { eaten, local liquor made from fleshy } \\
\text { flower. Seed oil is medicinal and } \\
\text { used for massage and cooking. Fruit } \\
\text { pulp can be edible too }\end{array}$ \\
\hline 67 & $\begin{array}{l}\text { Manilkara hexandra } \\
\text { Dub. TSLBG: } 2443\end{array}$ & April-May & Sapotaceae & Rayan & 1 & 3 & 1 & Ripe fruits are sweet and edible \\
\hline 68 & $\begin{array}{l}\text { Marsilea minuta L. } \\
\text { TSLBG: } 2446\end{array}$ & $\begin{array}{l}\text { In water } \\
\text { bodies } \\
\text { throughout } \\
\text { the year }\end{array}$ & Marsileaceae & Chabarchilu/Chilo & 3 & 1 & 3 & $\begin{array}{l}\text { Tender leaves are stir-fried with } \\
\text { fresh pigeon pea beans with spices } \\
\text { as a leafy vegetable }\end{array}$ \\
\hline 69 & $\begin{array}{l}\text { Momordica dioica } \\
\text { Roxb. TSLBG: } 2449\end{array}$ & July-Sept & Cucurbitaceae & $\begin{array}{l}\text { Kantola/Kotno/ } \\
\text { Kankoda }\end{array}$ & 5 & 3 & 4 & $\begin{array}{l}\text { Fruit is cooked as a vegetable with } \\
\text { spices stir-fried in oil }\end{array}$ \\
\hline 70 & $\begin{array}{l}\text { Morinda tomentosa } \\
\text { Heyne ex Roth syn M. } \\
\text { Tinctoria Roxb. TSLBG: } \\
2472\end{array}$ & Sept & Rubiaceae & Aal & 1 & 3 & 2 & Ripe fruits are edible \\
\hline 71 & $\begin{array}{l}\text { Moringa concanensis } \\
\text { Nimmo. TSLBG: } 2455\end{array}$ & Sept-Feb & Moringaceae & Hengvo & 1 & 6 & 2 & $\begin{array}{l}\text { The leaves and flowers are thoroughly } \\
\text { washed and consumed as a leafy } \\
\text { vegetable stir-fried in oil with spices }\end{array}$ \\
\hline 72 & $\begin{array}{l}\text { Moringa oleifera Lamk. } \\
\text { TSLBG: } 2499\end{array}$ & Oct-Mar & Moringaceae & Saragvo & 1 & 6 & 1 & $\begin{array}{l}\text { Fruit pods are used as a vegetable } \\
\text { in daal and boiled vegetable with } \\
\text { spices. The leaves and flowers are } \\
\text { also used as a leafy vegetable } \\
\text { either boiled or stir-fried in oil }\end{array}$ \\
\hline 73 & $\begin{array}{l}\text { Phoenix sylvestris (L.) } \\
\text { Roxb. TSLBG: } 2528\end{array}$ & Jan-June & Arecaceae & Khajuri & 1 & 3 & 4 & The fruit is edible \\
\hline 74 & $\begin{array}{l}\text { Phyllanthus emblica L. } \\
\text { TSLBG: } 2487\end{array}$ & Oct-Feb & Euphorbiaceae & Ambli/amla & 1 & 3 & 2 & $\begin{array}{l}\text { Fruits are edible raw or pickled, } \\
\text { pickled vegetable also made. Dried } \\
\text { fruit powder used in medicines }\end{array}$ \\
\hline 75 & $\begin{array}{l}\text { Pleurotus sp. TSLBG: } \\
2505\end{array}$ & July-Aug & Pleurotaceae & $\begin{array}{l}\text { Vansitro/Nans } \\
\text { naphool }\end{array}$ & & 6 & 2 & $\begin{array}{l}\text { The mushrooms are washed and } \\
\text { cleaned and stir-fried with onions } \\
\text { and spices }\end{array}$ \\
\hline 76 & Pueraria tuberosa & All year & Fabaceae & Bohon & 4 & 1 & 3 & Stir-fried or boiled with spices \\
\hline
\end{tabular}

(Roxb.) DC. TSLBG: 2474 
Table 1 List of wild edible species used by the Vasavas (Continued)

\begin{tabular}{|c|c|c|c|c|c|c|c|c|}
\hline Sr. No. & $\begin{array}{l}\text { Botanical names and } \\
\text { collection number }\end{array}$ & Season & Family/sub family & Vasavi name & $\begin{array}{l}\text { Plant } \\
\text { type }\end{array}$ & $\begin{array}{l}\text { Plant } \\
\text { part } \\
\text { used }\end{array}$ & $\begin{array}{l}\text { Habitat/ } \\
\text { location }\end{array}$ & Recipe and use \\
\hline 77 & $\begin{array}{l}\text { Randia spinosa } \\
\text { (Thumb.) BL. TSLBG: } \\
2468\end{array}$ & Jan-May & Rubiaceae & Galu & 2 & 3 & 1 & The fruits are edible in small amounts \\
\hline 78 & $\begin{array}{l}\text { Schleichera oleosa } \\
\text { Lour. TSLBG: } 2479\end{array}$ & Feb-July & Sapindaceae & Kusum & 1 & 3 & 1 & The ripe fruits are edible \\
\hline 79 & $\begin{array}{l}\text { Solanum nigrum L. } \\
\text { TSLBG: } 2458\end{array}$ & June-Nov & Solanaceae & Nagadyu & 2 & 6 & 4 & $\begin{array}{l}\text { The leaves are edible as leafy } \\
\text { vegetables and eaten boiled with } \\
\text { chili and salt. The fruits are edible } \\
\text { when ripe }\end{array}$ \\
\hline 80 & $\begin{array}{l}\text { Spondias acuminata } \\
\text { Roxb. TSLBG: } 2517\end{array}$ & May-June & Anacardiaceae & $\begin{array}{l}\text { Khatakumba/ } \\
\text { Khatambni }\end{array}$ & 1 & 3 & 2 & $\begin{array}{l}\text { Fruits are edible raw. Bark is } \\
\text { softened and applied on rashes }\end{array}$ \\
\hline 81 & $\begin{array}{l}\text { Syzygium cumini (L.) } \\
\text { Skeels TSLBG: } 2492\end{array}$ & May-Sept & Myrtaceae & Jambu & 1 & 3 & 1 & The ripe fruits are edible \\
\hline 82 & $\begin{array}{l}\text { Tamarindus indica L. } \\
\text { TSLBG: } 2512\end{array}$ & Feb-July & Caesalpiniaceae & Katra (Khatiambli) & 1 & 6 & 1 & $\begin{array}{l}\text { The leaves and flowers are made } \\
\text { into a leafy stir-fried vegetable with } \\
\text { spices. Chutney (sauce) of } \\
\text { unripe fruits made by crushing it } \\
\text { with spices and garlic. Ripe fruits are } \\
\text { used for culinary purpose as well. } \\
\text { Bark and seeds are used medicinally }\end{array}$ \\
\hline 83 & $\begin{array}{l}\text { Telosma pallida } \\
\text { (Roxb.) Craib. TSLBG: } \\
2523\end{array}$ & June-Nov & Asclepiadaceae & Varshadodi & 4 & 1 & 1 & $\begin{array}{l}\text { The tender leaves are eaten as leafy } \\
\text { vegetable either boiled or stir-fried } \\
\text { with spices }\end{array}$ \\
\hline 84 & $\begin{array}{l}\text { Terminalia bellirica } \\
\text { (Gaertn.) Roxb. TSLBG: } \\
2461\end{array}$ & Jan-May & Combretaceae & Behado & 1 & 3 & 1 & The red fruits are edible \\
\hline 85 & $\begin{array}{l}\text { Tinospora glabra } \\
\text { (Burm.f.) Merrill TSLBG: } \\
2480\end{array}$ & Jan-May & Menispermiaceae & Kamboli & 5 & 5 & 1 & $\begin{array}{l}\text { The leaves are tender; stem is cut } \\
\text { and stir-fried in oil and mixed with } \\
\text { other leafy vegetables }\end{array}$ \\
\hline 86 & $\begin{array}{l}\text { Wrightia tinctoria } \\
\text { (Roxb.) R. Br. TSLBG: } \\
2500\end{array}$ & March-June & Apocynaceae & $\begin{array}{l}\text { Safed Kuvad/Dudh } \\
\text { Kuvad }\end{array}$ & 1 & 6 & 1 & $\begin{array}{l}\text { Flowers are edible and stir-fried as } \\
\text { a vegetable with oil and spices }\end{array}$ \\
\hline 87 & $\begin{array}{l}\text { Wrightia tomentosa } \\
\text { Roem. \& Schult. } \\
\text { TSLBG: } 2514\end{array}$ & March-July & Apocynaceae & Danti-Kuvad & 1 & 6 & 1 & $\begin{array}{l}\text { Flowers are edible and stir-fried as } \\
\text { a vegetable with oil and spices }\end{array}$ \\
\hline 88 & $\begin{array}{l}\text { Ziziphus mauritiana } \\
\text { Lam. TSLBG: } 2511\end{array}$ & Jan-March & Rhamnaceae & Bor & 1 & 3 & 1 & The ripe fruits are edible \\
\hline 89 & $\begin{array}{l}\text { Ziziphus oenopila (L.) } \\
\text { Mill. TSLBG: } 2526\end{array}$ & Jan-April & Rhamnaceae & Emardi & 1 & 3 & 1 & The ripe fruits are edible \\
\hline 90 & $\begin{array}{l}\text { Ziziphus xylopyra } \\
\text { (Retz.) Willd. TSLBG: } \\
2439\end{array}$ & Jan-March & Rhamnaceae & Ghat bor & 1 & 3 & 1 & The ripe fruits are edible \\
\hline
\end{tabular}

Key to the numerical categorization: plant type: 1-tree, 2-shrub, 3-herb, 4-twiner, 5-climber; plant part used: 1-leaves, 2-flowers, 3-seed/fruits, 4-tuber/underground part, 5-young shoot, 6-multiple parts used; habitat/location: 1-field/village, 2-forest, 3-swamp, 4 -village + forest, 5—swamp + forest, 6-village + swamp, 7-all

the expert interviews was utilized to support interpretation of the quantitative findings.

\section{Results}

Through the key informant interviews, 90 species of wild edibles were identified (Table 1). These species belonged to 46 different botanical families; the families with the most number of species represented were Amaranthaceae (6 spp.), followed by Asclepiadaceae (5 spp.) and Dioscoreaceae (5 spp.). All Amaranthaceae species were collected for their leaves, while all Dioscoreaceae species for their aerial tubers. The family Asclepiadaceae had a more diverse pattern of plant utilization, with leaves, tubers, and fruits all used for cooking. Some of these species were used for medicinal purposes as well.

The average number of wild edible species mentioned by a key informant was 48.4 (median 51). The average number of wild edible species collected for fruits mentioned was 13.6 (median 13), for leaves was 14.5 (median 14), flowers 3.4 (median 3), tubers 5.1 
Table 2 Wild edibles with reported medicinal use (as reported by previous ethnobotanical study)

\begin{tabular}{|c|c|c|c|c|c|}
\hline Sr. No. & Botanical names & Season & Family/sub family & Vasavi name & Plant type \\
\hline 1. & Achyranthes aspera $\mathrm{L}$. & June-Dec & Amaranthaceae & Arpchinjudo & Shrub \\
\hline 2. & Aegle marmelos (L.) Corr. & April-June & Rutaceae & Bila (Bili) & Tree \\
\hline 3. & Alangium salvifolium (L. f.) Wang. & Oct-Jan & Alangiaceae & Aakna & Tree \\
\hline 4. & Amaranthus hybridus L. & June-Nov & Amaranthaceae & Red & Herb \\
\hline 5. & Amaranthus spinosus L. & June-Nov & Amaranthaceae & Kanto & Herb \\
\hline 6. & Amaranthus viridis $\mathrm{L}$. & June-Nov & Amaranthaceae & Tandaljo (desi) MATNU & Herb \\
\hline 7. & Annona squamosa $\mathrm{L}$. & Sept-Nov & Annonaceae & Aanusari & Tree \\
\hline 8. & Asparagus racemosus Willd. & All year & Liliaceae & Shatavari & Shrub \\
\hline 9. & Azadirachta indica A. Juss. & March-June & Meliaceae & Limdo & Tree \\
\hline 10. & Bacopa monnieri (L.) Wettest. & Sept-Jan & Scrophulariaceae & Nir brahmi/Bam & Herb \\
\hline 11. & Bambusa arundinacea (Retz.) Willd. & Once after 25 years & Poaceae & Vans & Tree \\
\hline 12. & Bauhinia racemosa Lam. & Feb-May & Caesalpiniae & Aachitro, Hinglo & Tree \\
\hline 13. & Bombax ceiba L. & Feb-March & Bombacaceae & Hambo, Samro & Tree \\
\hline 14. & Borassus flabellifer Linn. & Feb-May & Palmaceae & Tad & Tree \\
\hline 15. & Borreria articularis (L.f.) F.N.Williams & All year round & Rubiaceae & Ganthi & Herb \\
\hline 16. & $\begin{array}{l}\text { Bridelia squamosa (Lamk.) } \\
\text { Gehrmann. Syn. Bridelia retusa Spreng. }\end{array}$ & Jan-Feb & Euphorbiaceae & Akano (tree) & Tree \\
\hline 17. & Buchanania cochinchinensis (Lour.) Almeida & Feb-May & Anacardiaceae & Charoli & Tree \\
\hline 18. & Cassia tora $\mathrm{L}$. & June-Aug & Fabaceae & Chinjudo & Shrub \\
\hline 19. & Celosia argentea $\mathrm{L}$. & June-Oct & Amaranthaceae & Lemdi & Shrub \\
\hline 20. & Ceropegia bulbosa Roxb. & July-Aug & Asclepiadaceae & Sap okoni & Herb \\
\hline 21. & Chenopodium album L. & June-Nov & Chenopodiaceae & Chil Bhaji & Herb \\
\hline 22. & Chlorophytum borivalianum Sant. \& Fernand & June-Aug & Liliaceae & Kuvlu & Herb \\
\hline 23. & Chlorophytum tuberosum (Roxb.) Baker & June-Aug & Liliaceae & Dholi musli/Kuvli & Herb \\
\hline 24. & Cocculus hirsutus (L.) Diels. & All year round & Menispermiaceae & Vasano/Vasanvel & Climber \\
\hline 25. & Cordia dichotoma Forst. f. & $\begin{array}{l}\text { Dec-Feb (flower) } \\
\text { March-June (fruit) }\end{array}$ & Ebenaceae & Gunda (green and chikna) & \\
\hline 26. & Dalbergia volubilis Roxb. Cor. PI. & June-Nov & Fabaceae & Kinhariyu/Pingush & Climber (woody) \\
\hline 27. & Dioscorea belophylla Voigt. & Aug-Sept & Dioscoreaceae & Huvi & Twiner \\
\hline 28. & Dioscorea bulbifera $\mathrm{L}$. & June-July & Dioscoreaceae & Kadvo kand & Twiner \\
\hline 29. & Dioscorea hispida Dennstd. & Aug-Sept & Dioscoreaceae & Manovaj & Twiner \\
\hline 30. & Dioscorea pentaphylla L. & Aug-Sept & Dioscoreaceae & Huvdo & Twiner \\
\hline 31. & Diospyros melanoxylon Roxb. & May-June & Ebenaceae & Timru & Tree \\
\hline 32. & Dregea volubilis (L.f.) Benth. ex Hook.f. & Sept-Feb. & Asclepiadaceae & Kadvi shir & Climber \\
\hline 33. & Enicostema littorale Bl. & June-Aug & Gentianaceae & Mamejavo/Kadvi Nai & Herb \\
\hline 34. & Ficus hispida L.f. & May-July & Moraceae & Umbo/Koth Umbo & Tree \\
\hline 35. & Garuga pinnata Roxb. & Jan-May & Burseraceae & Kakaro & Tree \\
\hline 36. & Heracleum grandis (Dalz. \& Gibs.) Mukh. & All year & Umbellifera & Bokhudo & Undershrub \\
\hline 37. & Holarhena antidysenterica (Heyne ex Roth) Wall.ex DC. & June-Aug & Apocynaceae & Kunvad & Shrub \\
\hline 38. & Holoptelea integrifolia (Roxb.) Planch. & Jan-May & Ulmaceae & Kunjo, Punjo & Tree \\
\hline 39. & Holostemma annularium (Roxb.) K Schum. & June-Aug & Asclepiadaceae & Nanshiri/meethi shir & Twiner \\
\hline 40. & Ipomoea aquatica Forsk. & All year & Convolvulaceae & $\mathrm{Nal}$ & Aquatic herb \\
\hline 41. & Ipomoea carnea ssp.fistulosa (Mortex ex Choisy) Austin & July-Nov & Convolvulaceae & Nihuto & Shrub \\
\hline 42. & Kirganelia reticulata (Poir.) Bail. & July-Aug & Euphorbiaceae & Kinhariyu/Kalichini & Shrub \\
\hline 43. & Leea macrophylla Roxb. ex Hornem & July-Aug & Leeaceae & Motu Dhinu & Herb \\
\hline
\end{tabular}


Table 2 Wild edibles with reported medicinal use (as reported by previous ethnobotanical study) (Continued)

\begin{tabular}{|c|c|c|c|c|c|}
\hline Sr. No. & Botanical names & Season & Family/sub family & Vasavi name & Plant type \\
\hline 44. & Limonia acidissima L. & Nov-March & Rutaceae & Kotha & Tree \\
\hline 45. & Madhuca indica Gmel. & March-July & Sapotaceae & Mahuda & Tree \\
\hline 46. & Manilkara hexandra Dub. & April-May & Sapotaceae & Rayan & Tree \\
\hline 47. & Momordica dioica Roxb. & July-Sept & Cucurbitaceae & Kantola/Kotno/Kankoda & Climber \\
\hline 48. & Moringa concanensis Nimmo. & Sept-Feb & Moringaceae & Hengvo & Tree \\
\hline 49. & Moringa oleifera Lamk. & Oct-Mar & Moringaceae & Saragvo & Tree \\
\hline 50. & Phoenix sylvestris (L.) Roxb. & Jan-June & Arecaceae & Khajuri & Tree \\
\hline 51. & Phyllanthus emblica L. & Oct-Feb & Euphorbiaceae & Ambli/amla & Tree \\
\hline 52. & Pueraria tuberosa (Roxb.) DC. & All year & Fabaceae & Bohon & Twiner \\
\hline 53. & Schleichera oleosa Lour. & Feb-July & Sapindaceae & Kusum & Tree \\
\hline 54. & Solanum nigrum Linn. & June-Nov & Solanaceae & Nagadyu & Shrub \\
\hline 55. & Syzygium cumini (L.) Skeels & May-Sept & Myrtaceae & Jambu & Tree \\
\hline 56. & Tamarindus indica L. & Feb-July & Caesalpiniaceae & Katra (Khati ambli) & Tree \\
\hline 57. & Terminalia bellirica (Gaertn.) Roxb. & Jan-May & Combretaceae & Behado & Tree \\
\hline 58. & Tinospora glabra (Burm.f.) & Jan-May & Menispermiaceae & Kamboli & Creeper \\
\hline 59. & Wrightia tinctoria (Roxb.) R. Br. & March-June & Apocynaceae & Safed Kuvad/Dudh Kuvad & Tree \\
\hline 60. & Zizyphus mauritiana Lam. & Jan-March & Rhamnaceae & Bor & Tree \\
\hline
\end{tabular}

Table 3 Wild edible plants from Table 1 that were also reported in the GSFDC list as NWFP collection. Prices are mentioned in INR/kg and INR per quintal

\begin{tabular}{|c|c|c|c|c|c|c|c|}
\hline Sr. No. & Botanical names & Family/sub family & Vasavi name & Plant type & Plant parts & INR/kg & INR/q \\
\hline 1. & Achyranthes aspera $\mathrm{L}$. & Amaranthaceae & Arpchinjudo & Shrub & Leaves & 10 & 1000 \\
\hline 2. & Aegle marmelos (L.) Corr. & Rutaceae & Bila (Bili) & Tree & Fruit & 12 & 1200 \\
\hline 3. & Asparagus racemosus Willd. & Liliaceae & Shatavari & Shrub & Tuberous root & 200 & 20,000 \\
\hline 4. & Azadirachta indica A. Juss. & Meliaceae & Limdo & Tree & Flower and fruit & & \\
\hline 5. & Bambusa arundinacea (Retz.) Willd. & Poaceae & Vans & Tree & Young shoot & 20 & 2000 \\
\hline 6. & Boerhavia diffusa $\mathrm{L}$. & Nyctaginaceae & $\begin{array}{l}\text { Dhagarphodiyu/ } \\
\text { Patharphodiyu }\end{array}$ & Herb & Leaf and tender stem & 60 & 6000 \\
\hline 7. & Cassia tora $\mathrm{L}$. & Fabaceae & Chinjudo & Shrub & Seeds & 20 & 2000 \\
\hline 7. & Cassia tora $\mathrm{L}$. & Fabaceae & Chinjudo & Shrub & Pods & 5 & 500 \\
\hline 8. & Chlorophytum tuberosum (Roxb.) Baker & Liliaceae & Dholi musli/Kuvli & Herb & Tuberous root grade 1 & 600 & 60,000 \\
\hline 8. & Chlorophytum tuberosum (Roxb.) Baker & Liliaceae & Dholi musli/Kuvli & Herb & Tuberous root grade 2 & 350 & 35,000 \\
\hline 9. & Enicostema littorale BI. & Gentianaceae & Mamejavo/Kadvi Nai & Herb & Leaf & 60 & 6000 \\
\hline 10. & $\begin{array}{l}\text { Holarhena antidysenterica } \\
\text { (Heyne ex Roth) Wall.ex DC. }\end{array}$ & Apocynaceae & Kunvad & Shrub & Leaves & 40 & 4000 \\
\hline 11. & Limonia acidissima $\mathrm{L}$. & Rutaceae & Kotha & Tree & Seed & 30 & 3000 \\
\hline 11. & Limonia acidissima $\mathrm{L}$. & Rutaceae & Kotha & Tree & Fruit pulp & 500 & 50,000 \\
\hline 12. & Phyllanthus emblica L. & Euphorbiaceae & Ambli/amla & Tree & Seed & 600 & 60,000 \\
\hline 12. & Phyllanthus emblica L. & Euphorbiaceae & Ambli/amla & Tree & Fruit pulp & 28 & 2800 \\
\hline 13. & Syzygium cumini (L.) Skeels & Myrtaceae & Jambu & Tree & Fruit & 10 & 1000 \\
\hline 14. & Terminalia bellirica (Gaertn.) Roxb. & Combretaceae & Behado & Tree & Bark pulp & 38 & 3800 \\
\hline 14. & Terminalia bellirica (Gaertn.) Roxb. & Combretaceae & Behado & Tree & Whole fruit & 4 & 400 \\
\hline 14. & Terminalia bellirica (Gaertn.) Roxb. & Combretaceae & Behado & Tree & Seed & 30 & 3000 \\
\hline 15. & Tinospora glabra (Burm.f.) & Menispermiaceae & Kamboli & Creeper & Stem & 20 & 2000 \\
\hline
\end{tabular}


(Median 5), and young shoots 2.1 (median 2), and average wild edibles with multiple uses mentioned was 9.5 (median 9).

The Vasavas were found to prefer leafy greens either stir-fried or boiled and to consume them in combination with other distinct-tasting (sour or bitter) leafy greens and crushed chilies. Tubers, leaves, and shoots were sometimes boiled and then blended with yoghurt or buttermilk to weaken the mucilage. The use of oil and spices other than salt and chilies in their recipes was minimal. Fruits were often collected recreationally and sometimes pickled and preserved.

A comparison of the compiled list against a preceding list of ethnomedicinal plants from the study area [47] suggested that 60 out of the 90 wild edibles identified are also medicinally used by the Vasavas (Table 2). A further comparison of the list against the Gujarat State Forest Development Corporation's (GSFDC) NWFP collection revealed that 15 out of the 90 species also carry economic values when sold to GSFDC (Table 3).

Figure 4 represents the Euler proportional distribution [51] for the locations of collection. The largest number of species (37) was collected from village habitats only, followed by the groups only collected from forest habitats (20 spp.), and from both village and forest habitats (20 spp.). Six species were collected only from swamp habitats, while two species were collected from both villages and swamp habitats. Five species showed no habitat preference, collected at all three location groups. Three of these species were from the genus Amaranthus, and one species each was from genera Commelina and Ipomea.

Different habitats were preferred for collection at different times of the year. Village habitats were extensively used during the months of March and July (Fig. 5).

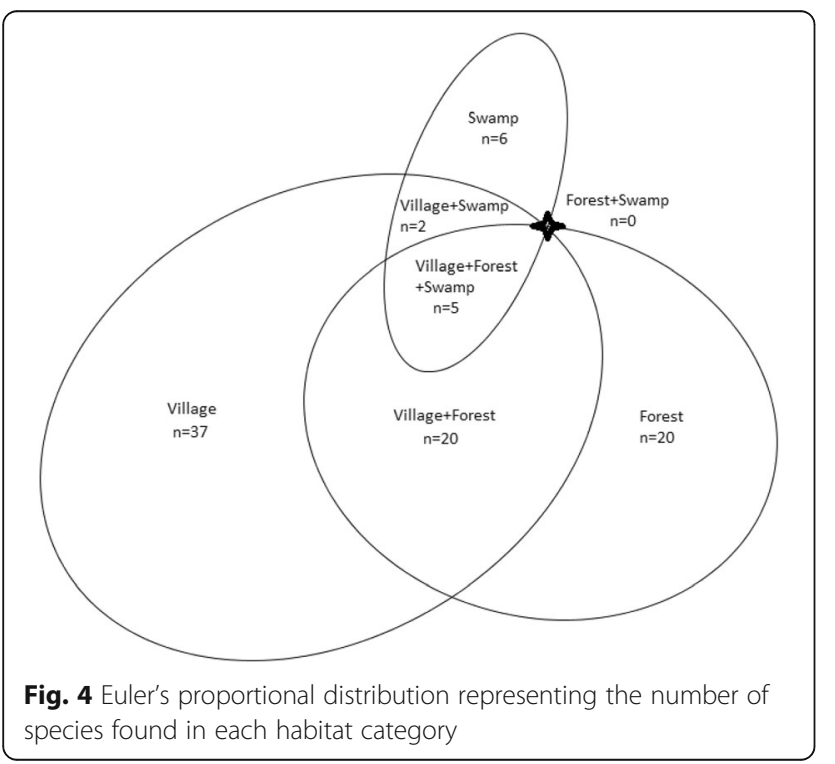

These periods are marked, respectively, with the onset of summer and the beginning of the Kharif cropping season. Forests were most utilized in August (9 spp.) and least utilized in December, the latter of which coincides with dry winter and was generally the least active month for collection across all habitats. Swamps were used more regularly across the year, with 5-6 species collected at any given time.

A large number of tree species were collected from village habitats between January and June, while more herb species were collected from June to December (Fig. 6). The number of tree species collected from forest habitats was relatively constant across seasons, whereas collection of herb and shrub species in forests was more frequent between June and September. The numbers of herb, shrub, and climber species from swamp habitats remained constant throughout the year. For species collected from both villages and forests, collection of shrub species increased between May and December, while tree species were mainly collected from January to July. Across all habitats, the collection of herb species increased during the months of May to September.

Seasonal consumption patterns for each plant part are shown in Fig. 7. Twenty species of leafy vegetables were collected during the monsoon season of June to September, while seeds and fruits were collected, probably to supplement the diet during the dry and hot summer period, between February and May.

Of the species originating from village habitats, leafy species dominate from June to November (Fig. 8). In contrast, more fruits and seeds were utilized during the dry period of January to May. Utilization of forests as a source of leafy vegetables was negligible; species collected for multiple parts dominated these habitats, followed by fruits and seeds mainly collected from January to May. The number of leafy species harvested from both village and forest habitats was highest from June to October. No tubers were exclusively sourced from forests; they were rather collected from combined village and forest habitats. Young shoots were collected from forest habitats from July to October and then from village habitats from January to May. Across all habitats, the number of leafy species collected increased between June and November.

The majority of fruits in the Vasavas' diet were contributed by tree species (Table 4), while leafy vegetables were mostly sourced from herb and shrub species. Trees were mainly utilized as edible fruits or for multiple parts (refer to the "Categorization of species" section), shrubs for multiple parts, and herbs for leaves. The main sources of tubers were twiners, and edible flowers were mainly sourced from trees, shrubs, and herbs.

As previously mentioned, village group discussions were open-ended, guided towards conversations about 


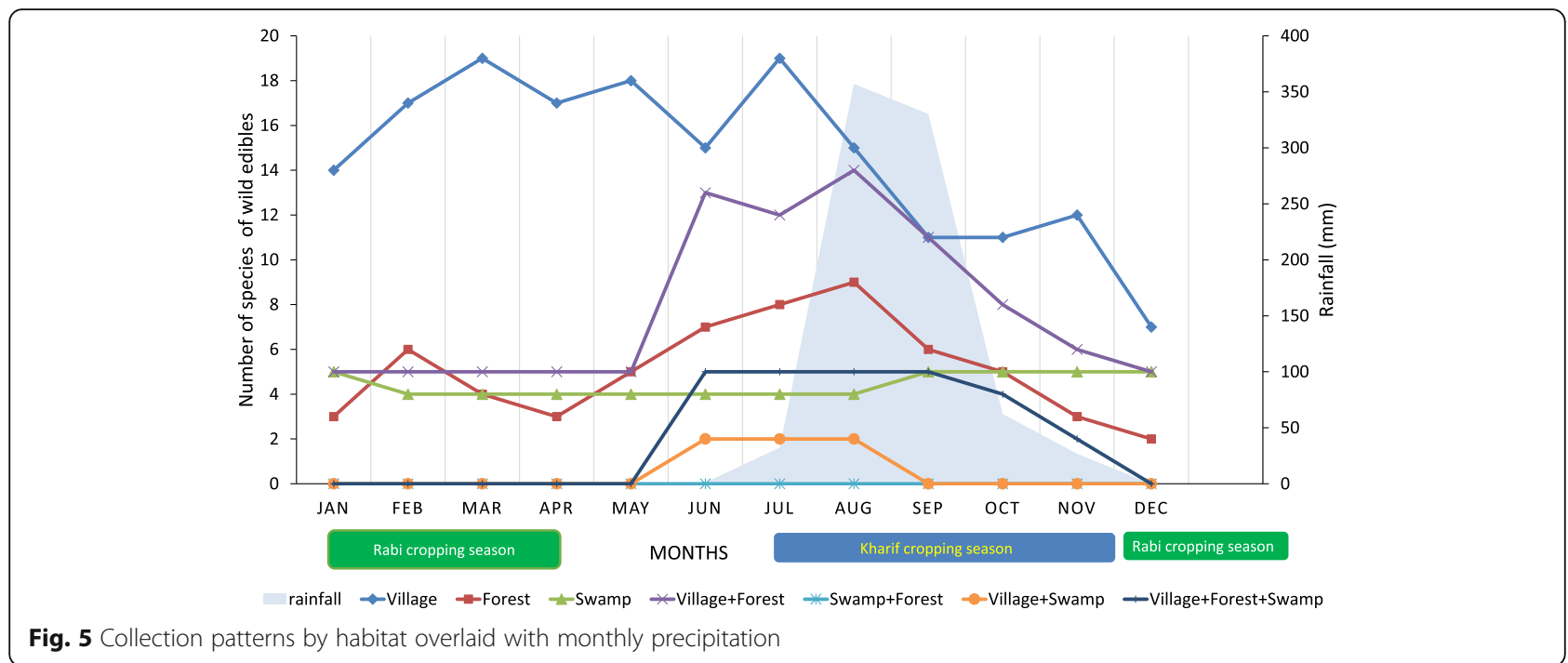

the consumption patterns of wild edibles past and present. When asked whether consumption and utilization of wild edibles had increased, decreased, or remained unchanged since as distant a past as they could remember, all respondents unanimously stated that their consumption had decreased, a response subsequently repeated in the expert interviews as well. Participants in group discussions highlighted several reasons for this change, for example the inability of children to identify species and participate in their collection, and their preference for cultivated vegetables. Comments were also made that the availability of certain species had decreased in their respective habitats, and thus, villagers would need to travel further into the forest to collect a sufficient amount.

These answers were then used to design a section of the questionnaire for the expert interviews, in which they were asked to rank pairwise the predefined reasons for decreased consumption of wild edibles. The most common reason, ranked on the total score of 7 respondents, was decreased availability, followed by a change in food preferences and the lack of the knowledge needed to identify species (Table 5). The respondents also indicated that there was an increasing preference for cultivated edibles amongst the younger generation, who have insufficient time to go out and collect wild edibles, due to their work and household commitments. The lowest ranked reason was a reduced requirement for a safety net for times of need, such as famines and financial shortfalls.

\section{Discussion}

All-year sustenance from wild edibles

In this research, 90 species of wild edibles from 46 botanical families were identified as used by the Vasavas in

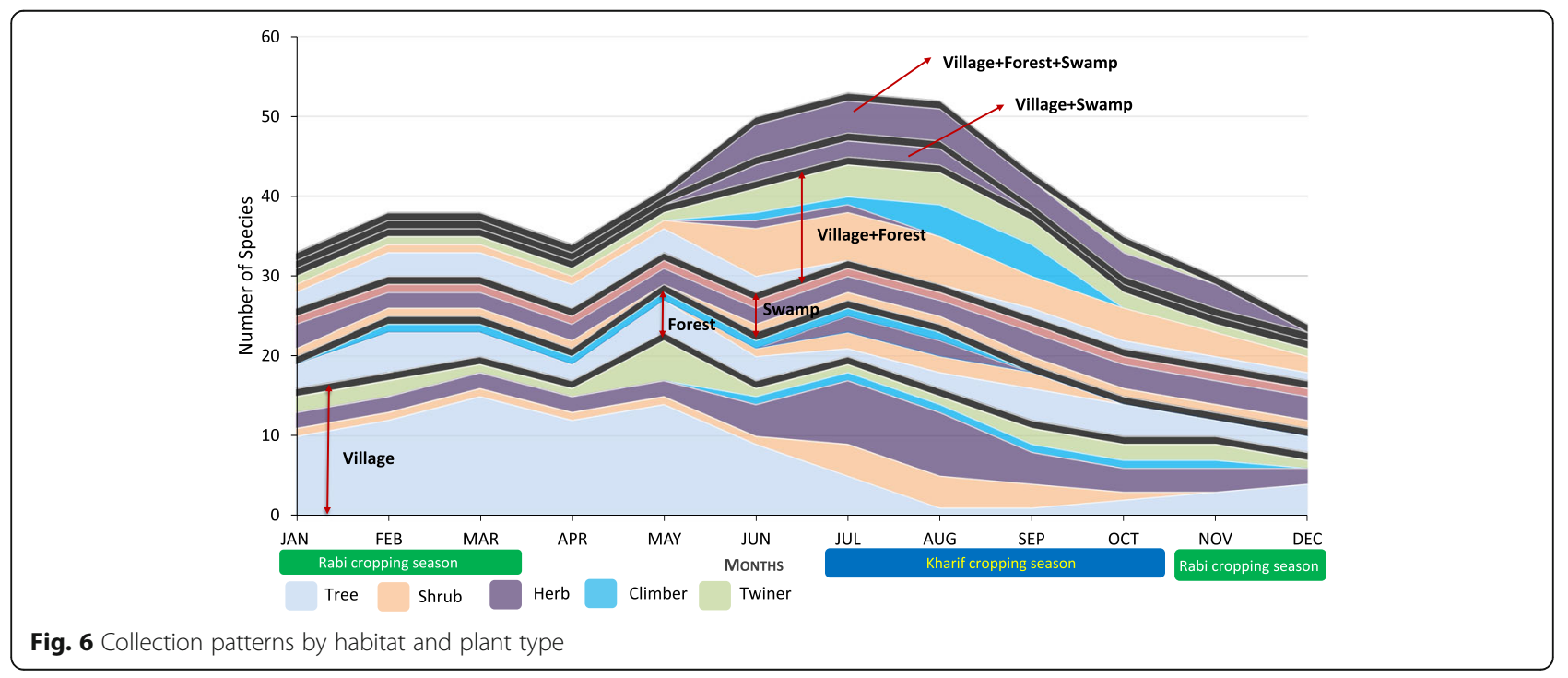




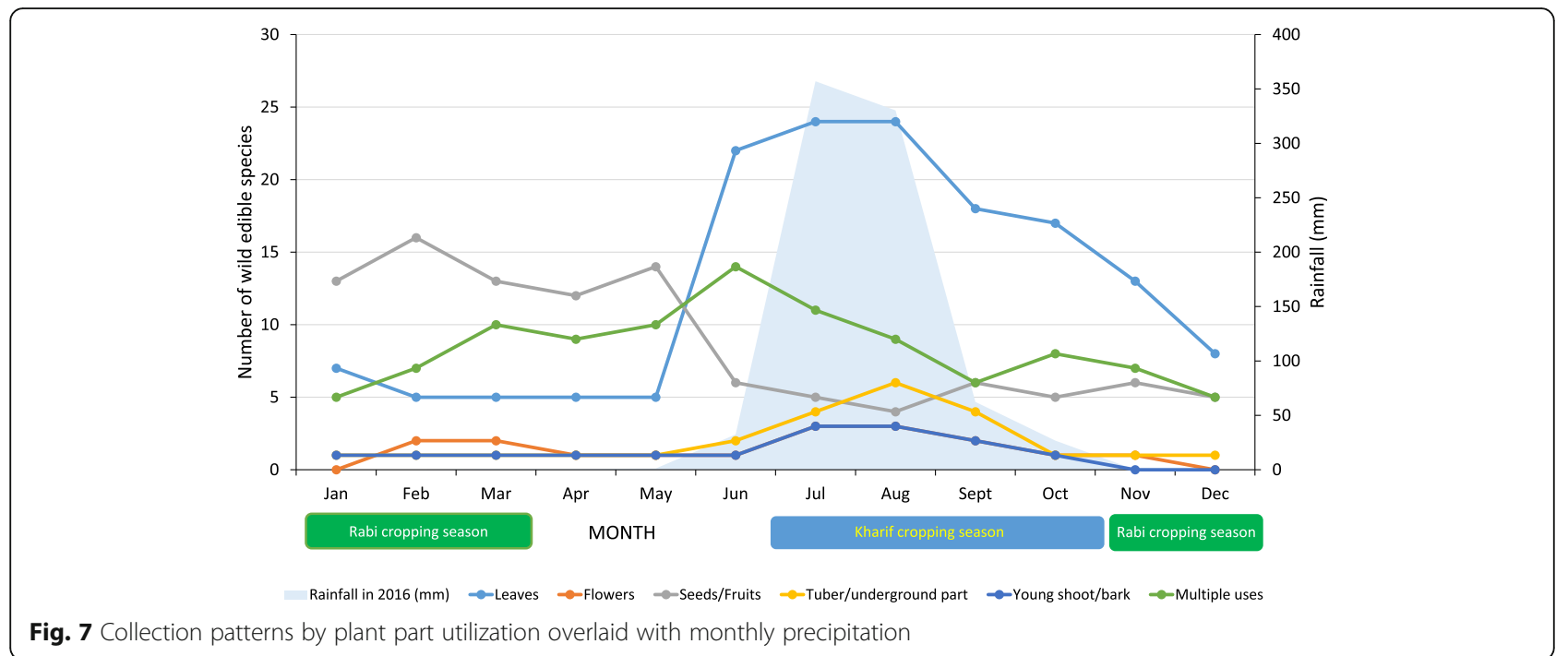

Dediapada Taluka. This is a high number of species compared to other studies previously undertaken in India: 61 species from Maharashtra located near Gujarat [52] and 22 species from the deciduous forests of Chhattisgarh in Central India [53]. From the northeastern state of Manipur, there were reports of 32 wild edibles by Pfoze et al. [15] and 68 species by Thongam et al. [54]. As for leafy vegetable plants, 24 species were identified in the present study, which is comparable to 21 species reported from Uttarakhand by Misra et al. [2].

To compare our results to other parts of Asia, 45 WEP species were recorded from the Lesser Himalayas in Pakistan [23], 87 and 252 from Thailand [50], 90 from the Mekong Delta region of Vietnam [22], 54 and 81 from Tibetan communities of the eastern part of the Tibetan Plateau [55, 56], and 185 (including 126 species of wild vegetables) from the Chinese (Han) [57]. Zou et al. [58] recorded more, noting the use of 335 taxa of wild vegetables in 10 villages of Hunan, China, whereas Ghorbani et al. [59] recorded the use of 173 wild food plants from 485 informants of four ethnic groups of the Naban valley of Xishuangbanna (a tropical area of south China), the latter being very heterogeneous in terms of elevation, inhabitants, and vegetation. To sum up, the numbers of WEPs recorded in India, Pakistan, and on the Tibetan Plateau are comparable with our results, apart from parts of Thailand and China, where the local communities use much longer lists of WEPs. The numbers of wild foods recorded in the studied community are also similar to those found in the Mediterranean countries, e.g., 82 wild food species as reported by Dolina and Luczaj [60].

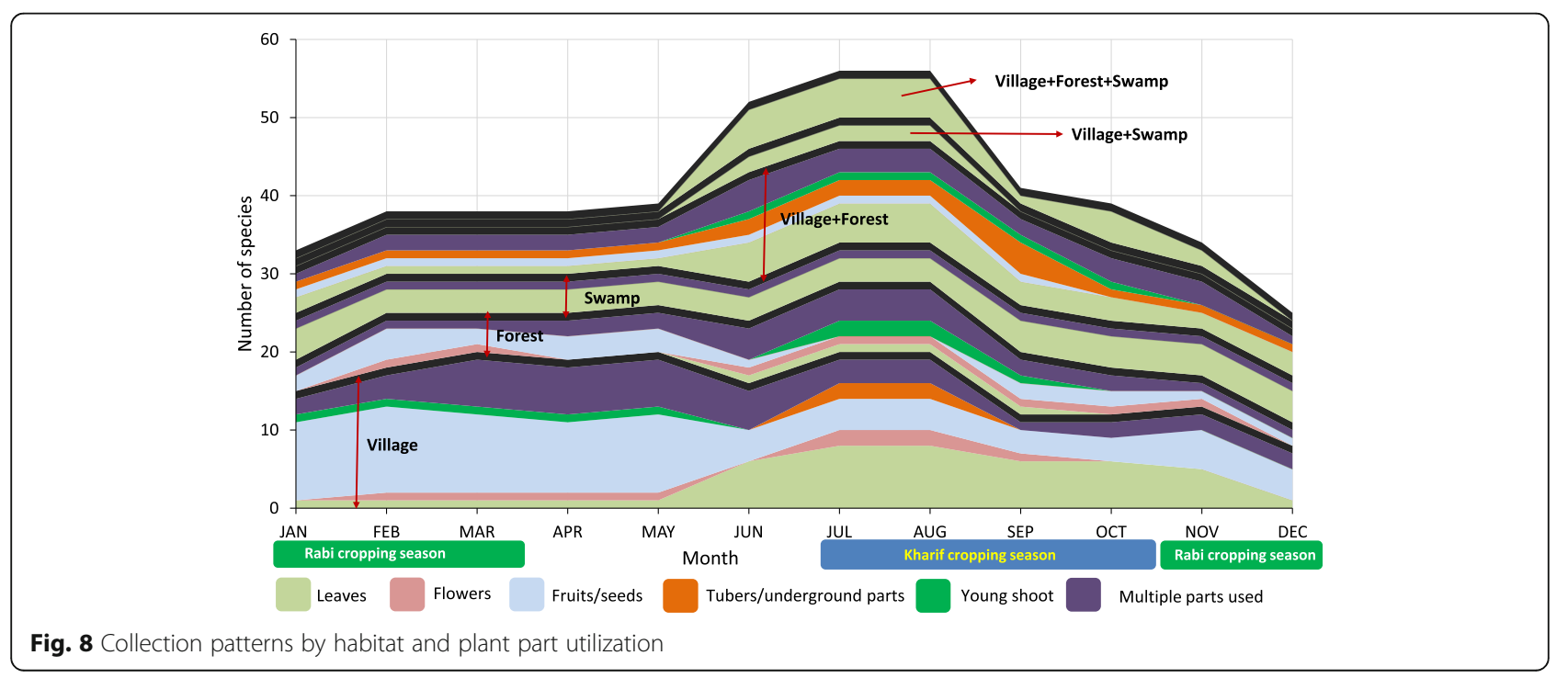


Table 4 Number of species by habit and plant part utilization

\begin{tabular}{lllllll}
\hline & Tree & Shrub & Herb & Twiner & Climber & Total \\
\hline Leaves & 0 & 6 & 13 & 2 & 3 & 24 \\
Flowers & 2 & 2 & 2 & 0 & 0 & 6 \\
Fruits & 21 & 2 & 0 & 1 & 2 & 26 \\
Tubers & 0 & 1 & 2 & 5 & 0 & 8 \\
Young shoot & 1 & 1 & 1 & 0 & 2 & 5 \\
Multiple parts & 12 & 3 & 2 & 1 & 1 & 19 \\
Total & 36 & 15 & 20 & 9 & 8 & \\
\hline
\end{tabular}

The species that have been the first reports from this area for their edible purpose are Ceropegia fantastica Sed and Clematis hedysarifolia DC.

The fact that wild vegetables are collected all year round (partly due to access to swampy habitats) is quite unique. In most of the papers dealing with wild foods, the times of gathering are usually mentioned as the "rainy season" [61] spring and early summer [57] or spring and autumn [62].

\section{Anthropogenically managed habitats for wild edible collection}

Anthropogenically managed habitats (e.g., villages, 37 spp.) were preferred to unmanaged habitats (e.g., forests, 20 spp.) for the collection of wild edibles (Fig. 4). This result is counter-intuitive given the term "wild," which is more generally associated with unmanaged environments. A similar observation was made by Cruz-Garcia and Price [50] and Misra et al. [2], in whose research man-made agro-ecosystems were found to be an important source of wild edibles. Combined with the number of species collected from both forest and village habitats (20), a total of 57 species were collected from anthropogenically managed habitats; this suggests that conservation efforts for wild edibles should be extended beyond natural forests, as human-inhabited areas also constitute important habitats for the community. Their occurrence is intertwined with traditional crop cultivation, forming agro-ecosystems providing both cultivated and wild economic plants [7].

While tree species from forests were collected all year round, their collection from villages was largely limited to the first half of the year, when only households with irrigation facilities can cultivate crops (Fig. 6). These tree species, therefore, are thought to be a vital, and possibly the only, source of micronutrients for a large proportion of the Vasavas, especially during the hot and dry summer.

Swamps were shown to be important habitats for leafy vegetables throughout the year (Fig. 8). While a large number of species were sourced from these habitats during the monsoon and post-monsoon seasons, their availability in villages and forests was negligible during summer. Hence, the maintenance of swamps and water bodies is likely to be crucial for the year-round inclusion of wild leafy vegetables in the diet.

\section{The role of wild edibles in dietary diversity}

Boedecker et al. [16] showed that the consumption of wild edibles was significantly related to an increased level of dietary diversity, which, in turn, has been associated with nutritional quality and therefore is a useful indicator for food security $[63,64]$. It is thus likely that the consumption of wild edibles would improve the nutritional status of the tribal population, who have limited access to anthropogenically produced plants. In the present case, the largest number of species belonged to fruits category, followed by leafy vegetables (Table 1). This finding suggests that the Vasavas enjoy a diverse supply of micronutrients, as many of them are abundant in plants that come under these two categories [14].

A FAO case study carried out in Gujarat reported that, for the Bhil tribe, wild foods contributed $30 \%$ of total energy intake for children and $24 \%$ for pregnant women. Furthermore, 41\% (39 of 95 items) of their foods were collected from uncultivated sources, showing a high dependence on wild edibles for both energy and micronutrients [48]. While a detailed nutritional investigation is beyond the remit of the present study, the above results indicated that the Vasavas are highly dependent on wild edibles as well, especially for micronutrients from fruits and leafy vegetables.

Wild leafy vegetables are an important source of carotenoids, including vitamin A [65]. Provided the leaves are consumed with fats, they can provide a year-round supply of vitamin A, as is the case of this tribe, where it is

Table 5 Pairwise ranking for the cause of decreased consumption of wild edibles

\begin{tabular}{llllllllll}
\hline Reasons for decreased consumption of edible wilds & V1 & V2 & V3 & V4 & V5 & V6 & V7 & Total score & Rank \\
\hline Decreased availability in wild & 3 & 4 & 3 & 4 & 3 & 4 & 2 & 23 & 1 \\
Change in food preference & 1 & 3 & 1 & 3 & 5 & 2 & 4 & 19 \\
Lack of knowledge of identifying edible vegetables & 2 & 2 & 3 & 4 & 2 & 2 & 3 & 18 & 2 \\
More preference to cultivated vegetables & 3 & 3 & 3 & 2 & 2 & 1 & 3 & 17 & 4 \\
No time to collect & 4 & 0 & 3 & 1 & 3 & 3 & 2 & 16 & 11 \\
Less desperate need or famine situation & 2 & 2 & 2 & 1 & 0 & 3 & 1 & 11 \\
\hline
\end{tabular}

Abbreviation village: V1 Bondiservan, V2 Vadhwa, V3 Khudardi, V4 Khokhraumar, V5 Zadoli, V6 Khairdipada, V7 Jamni 
noted that they consume leafy vegetables that are stir-fried in vegetable oil [66].

\section{Healthcare implications}

A comparative analysis between the present data and a previous ethnobotanical investigation focusing on medicinal plant usage (Table 2 ) revealed that $67 \%$ of edible species could also be used for medicinal purposes. This shows a great overlap of the food and healthcare functions of wild plants, as has been reported elsewhere $[22,53]$. Although it is difficult to quantify the health impact associated with the regular consumption of medicinal wild edibles, their inclusion in the daily diet at least ensures the maintenance of traditional medicinal knowledge through continued usage. The level of traditional medical knowledge has been rapidly declining in various parts of the world [67-69]; in the case of India, where medical pluralism is a long-standing cultural phenomenon [70], wild plants offer an important alternative to modern allopathic healthcare options, which are expensive and less accessible in many rural areas [70].

A study of the adolescent tribal population from nine states in India, including Gujarat, reported that amongst tribal people, deficiency in micronutrients, such as vitamin A, iron, free folic acid, and riboflavin, was more severe than that in energy and protein [71]. The same trend was also observed on the study site by a local allopathic doctor, who attested that vitamin $\mathrm{B}$ and iron deficiency (including genetic sickle cell anemia) were extremely common in the region. Given that leafy vegetables are widely recognized as a rich source of vitamin A, vitamin $\mathrm{B}$ complex, and iron and that cultivated greens as well as meat and dairy products are limited in the local market, wild leafy vegetables are a crucial source of these micronutrients [65]. A similar argument also holds for wild fruits, which are considered to be a good source of micronutrients and fibers, as nutritional studies of indigenous food from Jharkhand, India, indicate [72, 73]. Considering the relatively low cost associated with the acquisition of wild edibles compared to foods of equal nutritional value available on the commercial market, encouraging their continued consumption is likely to be a reasonable choice.

\section{Decreased consumption}

It was found that the primary reasons for decreased consumption of wild edibles were their decreased availability, changes in food preferences, and a lack of the knowledge needed to identify edible species (Table 2). The second and third reasons are somewhat interrelated, as changes in food preferences over a prolonged period of time may have exacerbated the lack of knowledge of species which are no longer familiar. Similar situations have been reported in the literature, where formal schooling [74] and lack of access to forests [67] led to a decline in traditional ecological knowledge and individual knowledge of medicinal plants.

The primary reason behind the preference for cultivated vegetables is thought to be a gradual shift in diet. For example, young children attending a school outside their village become acquainted with wheat and cultivated vegetables and at the same time have fewer opportunities to visit forests with those who can share their knowledge of edible (and medicinal) plants. This trend may potentially be reversed by, amongst other methods, maintaining children's contacts with wild edibles when they return home for holidays and modifying the education curriculum to cover more knowledge from within the region $[75,76]$.

Unlike other studies reporting "stigma" against wild edibles amongst tribal people in India [69], such a perception was not observed during the present study. The results from the expert interviews indicate that the Vasavas do not generally collect wild edibles as an economic safety net, the leading mechanism to produce "stigma" [69]; instead, the most cited reason for the decreased consumption of wild edibles was simply decreased availability. It is interesting to note that, while most families in the study region are still engaging in collection, most respondents at both the village group discussions and the expert interviews expressed the view that the overall consumption had significantly decreased. A similar finding was also reported from the Nanda Devi biosphere reserve in India by Misra et al. [2]. This phenomenon warrants further analysis, possibly through quantitative evaluation of biomass availability across habitats and seasons.

\section{Promotion of wild edibles}

Reyes-Garcia et al. reported that association of "cultural ecosystem services and values" explains the change in consumption patterns of wild edibles and that there had been a revival of certain wild species that were associated with "traditional" foods [68]. In other words, gastronomic culture could help maintain the consumption of certain wild edible plants. This is an important point to consider at the designing stage of intervention programs for conservation of traditional knowledge or dietary diversity. Associating cultural identity with wild edibles will likely maintain the familiarity of these plants and, by extension, promote their usage amongst younger generations. Examples of these efforts include community-based activities, such as recipe competitions and food tasting at village fairs, or workshops at schools and social gatherings.

\section{Conclusion}

The present study has demonstrated that the Vasava tribe's collective knowledge of wild edibles is vast and, 
more importantly, significantly contributes to dietary diversity throughout the year. The finding of the present study, namely that anthropologically managed habitats were preferred over natural environments for the collection of wild edibles, suggests that conservation efforts should be extended to village landscapes in addition to human-uninhabited landscapes. Of a wide range of wild edibles, tree species are likely playing an especially important role in the acquisition of micronutrients, as they can provide sustenance throughout the dry period. While there is no doubt that inclusion of these species in future development planning is important, pathways to ensure the spontaneous consumption of wild edibles need to be further developed at the same time. Continued consumption will likely maintain knowledge within the community and, through a spillover effect, along with the medicinal and industrial values attached to the species.

\section{Abbreviations}

FAO: Food and Agriculture Organization of the United Nations; GSFDC: Gujarat State Forest Development Corporation; NWFP: Non-wood forest products; WEP: Wild edible plants

\section{Acknowledgements}

We would like to extend our deep gratitude to Mr. Francis Mcwan, Mr. Himmat Chauhan, and Fr. John for their help in managing field logistics. We would like to thank Mr. Ruchir Purohit for his help in editing the map image. We also express our deep gratitude to all the respondents of this study for taking time for our interviews and sharing their knowledge.

\section{Funding}

The field study was funded by Japan Society for the Promotion of Science grant-in-aid (15H05244). The publication fee was funded by the Faculty of Biotechnology of the University of Rzeszów.

\section{Availability of data and materials}

A structured and organized version of the data is available from the first author upon reasonable request. Voucher specimens were deposited in the herbarium of The Serenity Library \& Botanical Garden, Botany outreach, Plot no. 96/12, of Koteshwar village, Motera, Gandhinagar, Gujarat, 380005, India.

\section{Authors' contributions}

SC, KO, and TT designed the research. SC, YS, and DL carried out the field study. SC analyzed the data. SC led the writing of the manuscript, with $\mathrm{KO}$, $T$, and $L L$ contributing critically to draft versions. All authors read and approved the final manuscript.

\section{Ethics approval and consent to participate}

The research was conducted in compliance with the Code of Ethics of the American Anthropological Association and the International Society of Ethnobiology Code of Ethics 76. Oral prior informed consent was acquired before all interviews. No ethical committee permits were required.

\section{Consent for publication}

Not applicable.

\section{Competing interests}

The authors declare that they have no competing interests.

\section{Publisher's Note}

Springer Nature remains neutral with regard to jurisdictional claims in published maps and institutional affiliations.

\section{Author details}

'Department of Global Agriculture Sciences, Graduate School of Agriculture and Life Sciences, The University of Tokyo, Tokyo 1138657, Japan. ${ }^{2}$ The Serenity Library \& Botanical Garden, Botany outreach, Plot no. 96/12, of Koteshwar village, Motera, Gandhinagar, Gujarat 380005, India. ${ }^{3}$ Bristol Veterinary School, University of Bristol, Langford, Somerset BS40 5DU, UK. ${ }^{4}$ Sustainable Agriculture Sciences Department, Rothamsted Research, Okehampton, Devon EX20 2SB, UK. ${ }^{5}$ Department of Botany, Faculty of Biotechnology, University of Rzeszów, Zelwerowicza 8B, 35-601 Rzeszów, Poland. ${ }^{6}$ Department of Biology, St. Xavier's College, Ahmedabad, Gujarat, India.

Received: 22 January 2018 Accepted: 1 August 2018

Published online: 29 August 2018

\section{References}

1. Mavengahama S, McLachlan M, de Clercq W. The role of wild vegetable species in household food security in maize based subsistence cropping systems. Food Secur. 2013;5(2):227-33. https://doi.org/10.1007/s12571-013-0243-2.

2. Misra S, Maikhuri RK, Kala CP, Rao KS, Saxena KG. Wild leafy vegetables: a study of their subsistence dietetic support to the inhabitants of Nanda Devi Biosphere Reserve, India. J Ethnobiol Ethnomed. 2008;4:15. https://doi.org/ 10.1186/1746-4269-4-15.

3. Ojelel S, Kakudidi EK. Wild edible plant species utilized by a subsistence farming community in Obalanga sub-county, Amuria district, Uganda. J Ethnobiol Ethnomed. 2015;11(7):1-8. https://doi.org/10.1186/1746-4269-11-7.

4. Sundriyal M, Sundriyal RC. Wild edible plants of the Sikkim Himalaya: marketing, value addition and implications for management. Econ Bot. 2004;58(2):300-15. https://doi.org/10.1663/0013-0001(2004)058[0300: WEPOTS]2.0.CO;2.

5. Bharucha Z, Pretty J. The roles and values of wild foods in agricultural systems. Philos Trans R Soc. 2010;365:2913-26. https://doi.org/10.1098/rstb. 2010.0123.

6. Menendez-Baceta G, Aceituno-Mata L, Tardío J, Reyes-García V, Pardo-deSantayana M. Wild edible plants traditionally gathered in Gorbeialdea (Biscay, Basque Country). Genet Resour Crop Evol. 2012;59(7):1329-47. https://doi.org/10.1007/s10722-011-9760-z

7. Turner NJ, Łuczaj $Ł J$, Migliorini P, et al. Edible and tended wild plants, traditional ecological knowledge and agroecology. CRC Crit Rev Plant Sci. 2011;30:198-225. https://doi.org/10.1080/07352689.2011.554492.

8. Ignacimuthu S, Ayyanar M, Sivaraman KS. Ethnobotanical investigations among tribes in Madurai District of Tamil Nadu (India). J Ethnobiol Ethnomed. 2006;2(25):1-7. https://doi.org/10.1186/1746-4269-2-25.

9. Purkayastha J, Nath SC, Islam M. Ethnobotany of medicinal plants from Dibru-Saikhowa Biosphere Reserve of Northeast India. Fitoterapia. 2005;76(1): 121-7. https://doi.org/10.1016/j.fitote.2004.10.012.

10. Qureshi R, Raza BG. Ethnobotany of plants used by the Thari people of Nara Desert Pakistan. Fitoterapia. 2008;79(6):468-73. https://doi.org/10.1016/j. fitote.2008.03.010

11. Bhandary MJ, Chandrashekar KR, Kaveriappa KM. Medical ethnobotany of the Siddis of Uttara Kannada district, Karnataka, India. J Ethnopharmacol. 1995;47(3):149-58. https://doi.org/10.1016/0378-8741(95)01274-H.

12. Harsha VH, Hebbar SS, Hegde GR, Shripathi V. Ethnomedical knowledge of plants used by Kunabi Tribe of Karnataka in India. Fitoterapia. 2002;73(4): 281-7. https://doi.org/10.1016/S0367-326X(02)00078-3.

13. Sundriyal M, Sundriyal RC, Sharma E, Purohit AN. Wild edibles and other useful plants from the Sikkim Himalaya, India. Oecologia Mont. 1998;7:43-54.

14. Grivetti LE, Ogle BM. Value of traditional foods in meeting macro- and micronutrient needs: the wild plant connection. Nutr Res Rev. 2000; 13(2000):31-46.

15. Pfoze NL, Kumar Y, Sheikh N, Myrboh B. Assessment of local dependency on selected wild edible plants and fruits from Senapati district, Manipur, Northeast India. Ethnobot Res Appl. 2012;10:357-67.

16. Boedecker J, Termote C, Assogbadjo AE, Van Damme P, Lachat C. Dietary contribution of wild edible plants to women's diets in the buffer zone around the Lama forest, Benin - an underutilized potential. Food Secur. 2014;6(6):833-49. https://doi.org/10.1007/s12571-014-0396-7.

17. Powell B, Kerr RB, Young SL, Johns T. The determinants of dietary diversity and nutrition: ethnonutrition knowledge of local people in the East Usambara Mountains, Tanzania. J Ethnobiol Ethnomed. 2017;13(23):1-12. https://doi.org/10.1186/s13002-017-0150-2. 
18. Delang CO. The role of wild food plants in poverty alleviation and biodiversity conservation in tropical countries. Prog Dev Stud. 2006;6(4):27586. https://doi.org/10.1191/1464993406ps143oa.

19. Samant SS, Dhar U. Diversity, endemism and economic potential of wild edible plants of Indian Himalaya. Int J Sustain Dev World Ecol. 1997;4(3): 179-91. https://doi.org/10.1080/13504509709469953.

20. Motlhanka DM, Makhabu SW. Medicinal and edible wild fruit plants of Botswana as emerging new crop opportunities. J Med Plants Res. 2011;5(10):1836-42.

21. Maikhuri RK, Rao KS, Saxena KG, Saxena KG. Bioprospecting of wild edibles for rural development in the central Himalayan Mountains of India. Mt Res Dev. 2004;24(2):110-3.

22. Ogle BM, Tuyet HT, Duyet HN. Food, feed or medicine: the multiple functions of edible wild plants in Vietnam. Econ Bot. 2003;57(1):103-17.

23. Abbasi AM, Khan MA, Shah MH, Shah MM, Pervez A. Ethnobotanical appraisal and cultural values of medicinally important wild edible vegetables of Lesser Himalayas-Pakistan. J Ethnobiol Ethnomed. 2013;9(66):1-13.

24. Reyes-García V, McDade T, Vadez V, et al. Non-market returns to traditional human capital: nutritional status and traditional knowledge in a native Amazonian society. J Dev Stud. 2008;44:217-32. https://doi.org/10.1080/00220380701789901.

25. Uusiku NP, Oelofse A, Duodu KG, Bester MJ, Faber M. Nutritional value of leafy vegetables of sub-Saharan Africa and their potential contribution to human health: a review. J Food Compos Anal. 2010;23(6):499-509. https:// doi.org/10.1016/j.jfca.2010.05.002

26. Quave $\mathrm{CL}$, Pieroni A. A reservoir of ethnobotanical knowledge informs resilient food security and health strategies in the Balkans. Nat Plants. 2015; 1(2):14021. https://doi.org/10.1038/nplants.2014.21.

27. Oshi NIJ, Iwakoti MOS, Ehlenbeck KAK. Wild vegetable species in Makawanpur District, Central Nepal: developing a priority setting approach for domestication to improve food security. Econ Bot. 2015;69(2):161-70. https://doi.org/10.1007/s12231-015-9310-2

28. Arnold M, Powell B, Shanley P, Sunderland TCH. Forests, biodiversity and food security. Int For Rev. 2011;13(3):259-64. https://doi.org/10.1505/ 146554811798293962.

29. Ladio AH, Lozada M. Patterns of use and knowledge of wild edible plants in distinct ecological environments: a case study of a Mapuche community from northwestern Patagonia. Biodivers Conserv. 2004;13(6):1153-73. https://doi.org/10.1023/B:BIOC.0000018150.79156.50.

30. Vandebroek I, Reyes-García V, de Albuquerque UP, Bussmann R, Pieroni A Local knowledge: who cares? J Ethnobiol Ethnomed. 2011;7(35) https://doi. org/10.1186/1746-4269-7-35.

31. Tiwari JK, Ballabha R, Tiwari P. Some promising wild edible plants of Srinagar and its adjacent area in Alaknada valley of Garhwal Himalaya, India. J Am Sci. 2010;6(4):167-74

32. Khan M, Kumar S, Hamal IA, Koul S. Wild edible plants of Sewa catchment area in Northwest Himalaya. J Plant Devel Sci. 2009;1(1\&2):1-7.

33. Singh B, Sultan P, Hassan QP, Gairola S, Bedi YS. Ethnobotany, traditional knowledge and diversity of wild edible plants and fungi: a case study in the Bandipora District of Kashmir Himalaya, India. J Herbs Spices Med Plants. 2016; https://doi.org/10.1080/10496475.2016.1193833.

34. Uprety Y, Poudel RC, Shrestha KK, Rajbhandary S, Tiwari NN, Shrestha UB, Asselin $\mathrm{H}$. Diversity of use and local knowledge of wild edible plant resources in Nepal. J Ethnobiol Ethnomed. 2012;8(1):16.

35. Ahmad K, Pieroni A. Folk knowledge of wild food plants among the tribal communities of Thakht-e-Sulaiman Hills, North-West Pakistan. J Ethnobiol Ethnomed. 2016;12:7.

36. Thakur D, Sharma A, Uniyal SK. Why they eat, what they eat: patterns of wild edible plants consumption in a tribal area of Western Himalaya. J Ethnobiol Ethnomed. 2017;13(1):70. https://doi.org/10.1186/s13002-017-0198-z.

37. Jeeva S. Horticultural potential of wild edible fruits used by the Khasi tribes of Meghalaya. J Hortic For. 2009;1(9):182-92.

38. Singh B, Sinha BK, Phukan SJ, Borthakur SK, Singh VN. Wild edible plants used by Garo tribes of Nokrek Biosphere Reserve in Meghalaya, India. Indian J Tradit Knowl. 2012;11(1):166-71.

39. Narayanan M, Anilkumar N, Balakrishnan V, Sivadasan M, Alfarhan $\mathrm{H}$, Alatar A. Wild edible plants used by the Kattunaikka, Paniya and Kuruma tribes of Wayanad District, Kerala, India. J Med Plants Res. 2011;5(15):3520-9.

40. Rasingam L. Ethnobotanical studies on the wild edible plants of Irula tribes of Pillur Valley, Coimbatore district, Tamil Nadu, India. Asian Pac J Trop Biomed. 2012;2(3 SUPPL) https://doi.org/10.1016/S2221-1691(12)60443-2.

41. Sundriyal M, Sundryal RC, Sharma E. Dietary use of wild plant resources in the Sikkim Himalaya, India. Econ Bot. 2004;58(4):626-38.
42. Aberoumand A, Deokule SS. Studies on nutritional values of some wild edible plants from Iran and India. Pak J Nutr. 2009;8(1):26-31.

43. Ji NK, Kumar RN, Patil N, Soni H. Studies on plant species used by tribal communities of Saputara and Purna forests, Dangs district, Gujarat. Indian J Tradit Knowl. 2007;6(2):368-74.

44. Gavali D, Sharma D. Traditional knowledge and biodiversity conservation in Gujarat. Indian J Tradit Knowl. 2004;3(1):51-8.

45. Bedi SJ. Ethnobotany of the Ratan Mahal Hills, Gujarat, India. Econ Bot. 1978; 32(3):278-84. https://doi.org/10.1007/BF02864701.

46. Patel PK, Patel MK. Ethnogynaecological uses of plants from Gujarat, India. Bangl J Plant Tax. 2012;19(1):93. https://doi.org/10.3329/bjpt.v19i1.10947.

47. Lancelot D'Cruz. Socio-economic development and traditional medicinal knowledge protection: Dediapada, South Gujarat, India. In: Pati RN, editor. Sustainable use of medicinal plants. Delhi: Abhijeet; 2012. p.68-79. ISBN: 9789381136492

48. Bhattacharjee L, Kothari G, Priya V, Nandi BK. The Bhil food system. Links to food security, nutrition and health. In Indigenous people's food systems: The many dimensions of culture, diversity and environment for nutrition and health, ed. Kuhnlein HV, Erasmus B, Spigelski D. Rome: FAO; 2009. p. 209-30.

49. Russel T. Pair Wise Ranking Made Easy. PLA Notes, IIED London. 1997;(28): 25-26.

50. Cruz-Garcia GS, Price LL. Ethnobotanical investigation of "wild" food plants used by rice farmers in Kalasin, Northeast Thailand. J Ethnobiol Ethnomed. 2011;7(1):33. https://doi.org/10.1186/1746-4269-7-33.

51. Micallef $L$, Rodgers P. euler APE: drawing area-proportional 3-Venn diagrams using ellipses. PLoS One. 2014;9(7). https://doi.org/10.1371/journal.pone. 0101717.

52. Mallesh RB. Wild edible plants of Chandrapur district, Maharashtra, India Indian J Nat Prod Resour. 2012;3(1):110-7

53. Kala CP. Aboriginal uses and management of ethnobotanical species in deciduous forests of Chhattisgarh state in India. J Ethnobiol Ethnomed. 2009;5:20. https://doi.org/10.1186/1746-4269-5-20.

54. Thongam B, Konsam S, Handique AK. Assessment of wild leafy vegetables traditionally consumed by the ethnic communities of Manipur, northeast India. J Ethnobiol Ethnomed. 2016;12(1):9. https://doi.org/10.1186/s13002016-0080-4.

55. Kang J, Kang Y, Ji X, Guo Q, Jacques G, Pietras M, Łuczaj N, Li D, Łuczaj Ł. Wild food plants and fungi used in the mycophilous Tibetan community of Zhagana (Tewo County, Gansu, China). J Ethnobiol Ethnomed. 2016;12(1):21.

56. Kang Y, Łuczaj Ł, Kang J, Wang F, Hou J, Guo Q. Wild food plants used by the Tibetans of Gongba Valley (Zhouqu county, Gansu, China). J Ethnobiol Ethnomed. 2014;10(1):20.

57. Kang Y, Łuczaj $Ł$, Kang J, Zhang S. Wild food plants and wild edible fungi in two valleys of the Qinling Mountains (Shaanxi, central China). J Ethnobiol Ethnomed. 2013;9(1):26

58. Zou X, Huang F, Hao L, Zhao J, Mao H, Zhang J, Ren S. The socio-economic importance of wild vegetable resources and their conservation: a case study from China. Kew Bull. 2010;65:577-82.https://doi.org/10.1007/s12225-010-9239-7.

59. Ghorbani A, Langenberger G, Sauerborn J. A comparison of the wild food plant use knowledge of ethnic minorities in Naban River Watershed National Nature Reserve, Yunnan, SW China. J Ethnobiol Ethnomed. 2012;8: 17. https://doi.org/10.1186/1746-4269-8-17.

60. Łuczaj $Ł$, Dolina K. A hundred years of change in wild vegetable use in southern Herzegovina. J Ethnopharmacol. 2015;166:297-304.

61. Ogle BM, Xuan Dung NN, Thanh Do T, Hambraeus L. The contribution of wild vegetables to micronutrient intakes among women: an example from the Mekong Delta, Vietnam. Ecol Food Nutr. 2001;40(2):159-84.

62. Pieroni A, Nebel S, Santoro RF, Heinrich M. Food for two seasons: culinary uses of non-cultivated local vegetables and mushrooms in a south Italian village. Int J Food Sci Nutr. 2005;56(4):245-72.

63. Torheim LE, Ouattara F, Diarra MM, et al. Nutrient adequacy and dietary diversity in rural Mali: association and determinants. Eur J Clin Nutr. 2004; 58(4):594-604. https://doi.org/10.1038/sj.ejcn.1601853.

64. Ruel MT. Is dietary diversity an indicator of food security or dietary quality? A review of measurement issues and research needs. Food Nutr Bull. 2003; 24(2):231-2.

65. Rajyalakshmi P, Venkatalaxmi K, Venkatalakshmamma K, Jyothsna $Y$, Balachandramani Devi K, Suneetha V. Total carotenoid and beta-carotene contents of forest green leafy vegetables consumed by tribals of south India. Plant Foods Hum Nutr. 2001;56(3):225-38. https://doi.org/10.1023/A: 1011125232097 
66. Johnson N, Grivetti LE. Gathering practices of Karen women: questionable contribution to beta-carotene intake. Int J Food Sci Nutr. 2002;53(6):489501.

67. Barreau A, Ibarra JT, Wyndham FS, Rojas A, Kozak RA. How can we teach our children if we cannot access the forest? Generational change in Mapuche knowledge of wild edible plants in Andean temperate ecosystems of Chile. J Ethnobiol. 2016;36(2):412-32. https://doi.org/10.2993/0278-0771-36.2.412.

68. Reyes-García V, Menendez-Baceta G, Aceituno-Mata L, et al. From famine foods to delicatessen: interpreting trends in the use of wild edible plants through cultural ecosystem services. Ecol Econ. 2015;120:303-11.0 https:// doi.org/10.1016/j.ecolecon.2015.11.003.

69. Cruz García GS. The mother-child nexus. Knowledge and valuation of wild food plants in Wayanad, Western Ghats, India. J Ethnobiol Ethnomed. 2006; 2:39. https://doi.org/10.1186/1746-4269-2-39.

70. Samal J. Situational analysis and future directions of AYUSH: an assessment through 5-year plans of India. J Intercult Ethnopharmacol. 2015;4(4):348. https://doi.org/10.5455/jice.20151101093011.

71. Rao KM, Balakrishna N, Laxmaiah A, Venkaiah K, Brahmam GNV. Diet and nutritional status of adolescent tribal population in nine states of India. Asia Pac J Clin Nutr. 2006;15:64-71.

72. Ghosh-Jerath S, Singh A, Magsumbol MS, Lyngdoh T, Kamboj P, Goldberg $\mathrm{G}$. Contribution of indigenous foods towards nutrient intakes and nutritional status of women in the Santhal tribal community of Jharkhand India. Public Health Nutr. 2016;19(12):2256-67. https://doi.org/10.1017/ S1368980016000318.

73. Ghosh-Jerath S, Singh A, Magsumbol MS, Kamboj P, Goldberg G. Exploring the potential of indigenous foods to address hidden hunger: nutritive value of indigenous foods of Santhal tribal community of Jharkhand, India. J Hunger Environ Nutr. 2016;11(4):548-68. https://doi.org/10.1080/19320248. 2016.1157545.

74. Voeks RA, Leony A. Forgetting the forest: assessing medicinal plant erosion in eastern Brazil. Econ Bot. 2004;58:294-306.

75. Ladio AH, Molares S. Evaluating traditional wild edible plant knowledge among teachers of Patagonia: patterns and prospects. Learn Individ Differ. 2013;27:241-9. https://doi.org/10.1016/j.lindif.2013.04.002.

76. Victoria Reyes-García, Eric Kightley, Isabel Ruiz-Mallén, Nuria Fuentes-Peláez, Katie Demps, Tomás Huanca, Maria Ruth Martínez-Rodríguez. Schooling and local environmental knowledge: Do they complement or substitute each other?. Int J Educ Dev. 2010:30(3):305-313

Ready to submit your research? Choose BMC and benefit from:

- fast, convenient online submission

- thorough peer review by experienced researchers in your field

- rapid publication on acceptance

- support for research data, including large and complex data types

- gold Open Access which fosters wider collaboration and increased citations

- maximum visibility for your research: over $100 \mathrm{M}$ website views per year

At $\mathrm{BMC}$, research is always in progress.

Learn more biomedcentral.com/submissions 